\title{
Methyl-cyclopentadienyl Ruthenium Compounds with 2,2'- Bipyridine Derivatives Display Strong Anticancer Activity and Multidrug Resistance Potential
}

\author{
Leonor Côrte-Real, ${ }^{\dagger, \bigcirc}$ Ricardo G. Teixeira, ${ }^{\dagger, \bigcirc}$ Patrícia Gírio, ${ }^{\dagger,}, \bigcirc$ Elisabeta Comsa, ${ }^{\ddagger}$ Alexis Moreno, ${ }^{\ddagger}$
} Rachad Nasr, ${ }^{\ddagger}$ Hélène Baubichon-Cortay, ${ }^{\ddagger}$ Fernando Avecilla, ${ }^{\S}$ Fernanda Marques, ${ }^{\prime \prime}$ M. Paula Robalo, ${ }^{\perp, \#}$ Paulo Mendes, ${ }^{\nabla}$ João P. Prates Ramalho, ${ }^{\nabla}$ M. Helena Garcia, ${ }^{\dagger}$ Pierre Falson, ${ }^{*},+$ and Andreia Valente ${ }^{*}, \dagger$

${ }^{\dagger}$ Centro de Química Estrutural, Faculdade de Ciências da Universidade de Lisboa, Campo Grande, 1749-016 Lisboa, Portugal

${ }^{\ddagger}$ Drug Resistance and Membrane Proteins Team, Molecular Biology and Structural Biochemistry Laboratory, UMR 5086 CNRS-UCBL1, IBCP 7 Passage du Vercors, 69367 Lyon Cedex 07, France

${ }^{\S}$ Grupo Xenomar, Centro de Investigacións Científicas Avanzadas (CICA), Departamento de Química, Facultade de Ciencias, Universidade da Coruña, Campus de A Coruña, 15071 A Coruña, Spain

"Centro de Ciências e Tecnologias Nucleares, Instituto Superior Técnico (C $\left.{ }^{2} \mathrm{TN} / \mathrm{IST}\right)$, Universidade de Lisboa, Estrada Nacional 10 (km 139.7), 2695-066 Bobadela LRS, Portugal

${ }^{\perp}$ Área Departamental de Engenharia Química, Instituto Superior de Engenharia de Lisboa, Instituto Politécnico de Lisboa, Rua Conselheiro Emídio Navarro, 1, 1959-007 Lisboa, Portugal

\#Centro de Química Estrutural, Complexo I, Instituto Superior Técnico, Universidade de Lisboa, Av. Rovisco Pais, 1049-001 Lisboa, Portugal

${ }^{\nabla}$ Departamento de Química and Centro de Química de Évora, Escola de Ciências e Tecnologia, Universidade de Évora, Rua Romão Ramalho, 59, 7000-671 Évora, Portugal

\section{Supporting Information}

ABSTRACT: New ruthenium methyl-cyclopentadienyl compounds bearing bipyridine derivatives with the general formula $\left[\mathrm{Ru}\left(\eta^{5}-\mathrm{MeCp}\right)\left(\mathrm{PPh}_{3}\right)\left(4,4^{\prime}-\mathrm{R}-2,2^{\prime}-\mathrm{bpy}\right)\right]^{+}(\mathbf{R u} 1, \mathrm{R}=\mathrm{H} ; \mathbf{R u} 2$, $\mathrm{R}=\mathrm{CH}_{3}$; and $\left.\mathrm{Ru} 3, \mathrm{R}=\mathrm{CH}_{2} \mathrm{OH}\right)$ have been synthesized and characterized by spectroscopic and analytical techniques. Rul crystallized in the monoclinic $P 2_{1} / c$, Ru 2 in the triclinic $\mathrm{P} \overline{1}$, and $\mathbf{R u} 3$ in the monoclinic $P 2_{1} / n$ space group. In all molecular structures, the ruthenium center adopts a "piano stool" distribution. Density functional theory calculations were performed for all complexes, and the results support spectroscopic data. Ru1 and Ru3 were poor substrates of the main multidrug resistance human pumps, $A B C B 1$, $A B C G 2, A B C C 1$, and $A B C C 2$, while $\mathbf{R u} 2$ displayed inhibitory properties of $\mathrm{ABCC} 1$ and $\mathrm{ABCC} 2$ pumps. Importantly, all compounds displayed a very high cytotoxic profile for ovarian cancer cells (sensitive and resistant) that was much more pronounced than that observed with cisplatin, making them very promising anticancer agents.

\section{INTRODUCTION}

The increasing research in the area of metallodrugs has positioned ruthenium complexes as promising drugs for cancer therapy, particularly because of the progression through clinical trials of some inorganic ruthenium(III) complexes, namely NAMI-A, $[\mathrm{ImH}]\left[\right.$ trans-RuCl$\left.{ }_{4}(\mathrm{DMSO}) \mathrm{Im}\right](\mathrm{Im}=$ imidazole $)$, and $\mathrm{KP} 1019$, [Hind] $\left[\right.$ trans- $\left.\mathrm{RuCl}_{4}(\text { ind })_{2}\right]$ (ind $=$ indazole $) .^{1-3}$ In addition, the growing research on ruthenium organometallic chemistry unveiled important features for the metallodrug field such as the lower toxicity of ruthenium drugs relative to platinum-based drugs (e.g., cisplatin, CDDP) and different cell

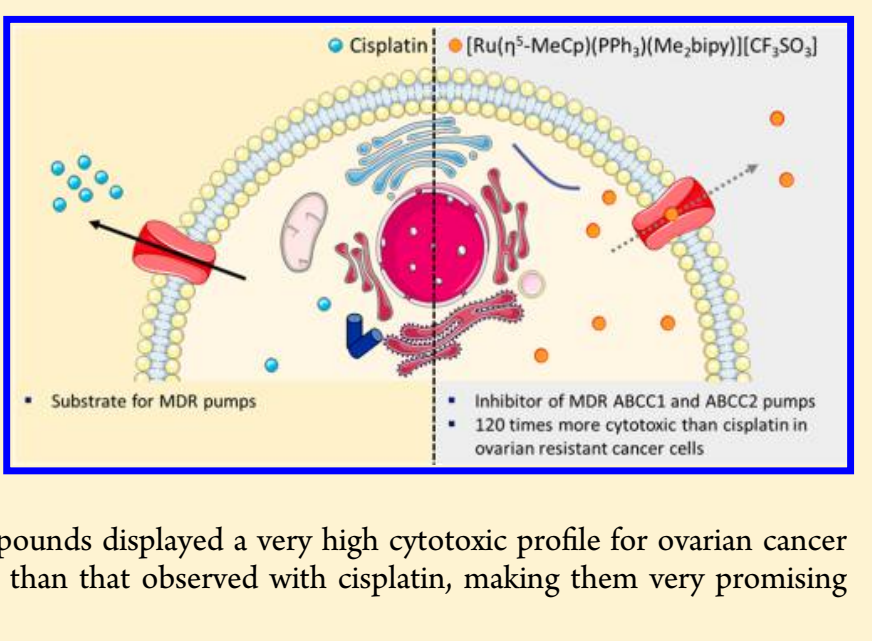

targets than DNA. ${ }^{4-6}$ Thus, different modes of action are possible, resulting in a better efficiency and less toxic side effects than those of the metallodrugs in clinical use.

Our research group has focused on the search for new $\mathrm{Ru}$ (II) and $\mathrm{Fe}$ (II) "piano stool" cationic complexes as anticancer agents. In this frame, diverse sets of complexes of the general formula $\left[\mathrm{M}^{\mathrm{II}}\left(\eta^{5}-\mathrm{C}_{5} \mathrm{H}_{5}\right)(\mathrm{PP})(\mathrm{L})\right]^{+}$were designed and synthesized, with $\mathrm{M}^{\mathrm{II}}=\mathrm{Ru}, \mathrm{Fe}$; $\mathrm{PP}=$ monodentate or bidentate

Received: February 9, 2018

Published: April 3, 2018 
Scheme 1. Synthetic Route of the New Ru(II) Complexes ${ }^{a}$

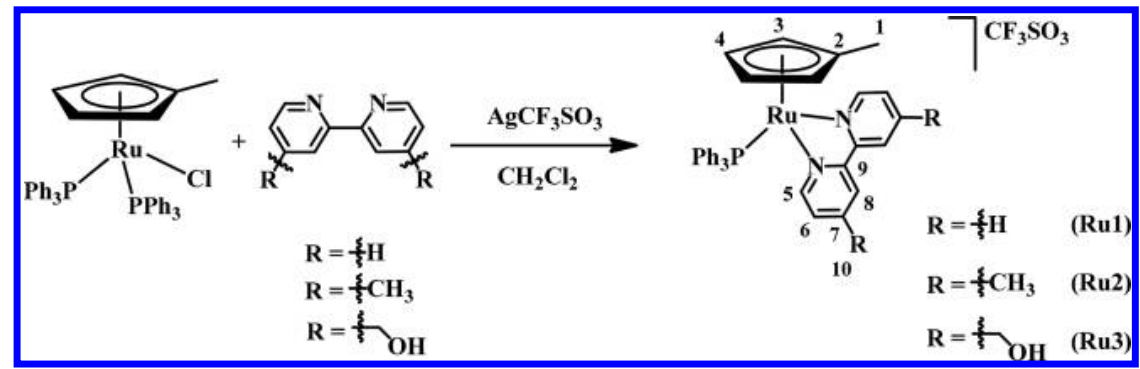

${ }^{a}$ Compounds are numbered for NMR assignments.

phosphane; and $\mathrm{L}=\mathrm{N}$-monodentate or $\mathrm{N}, \mathrm{N}^{\prime} / \mathrm{N}, \mathrm{O}$ bidentate heteroaromatic ligands. Most of these compounds present cytotoxic activities in the nano- and submicromolar range on several human cancer cell lines (e.g., MiaPaCa, LoVo, PC3, HL60, MCF7, HT29, A2780/A2780cisR, HeLa, MDAMB231, among others) with $\mathrm{IC}_{50}$ values generally lower than those of cisplatin, placing them among the best cytotoxic $\mathrm{Ru}(\mathrm{II})$ and $\mathrm{Fe}(\mathrm{II})$ organometallic complexes. ${ }^{7-20}$

Adequate substitutions on the coordinated phosphane and heteroaromatic ligands influence the electronic properties of these complexes, their biological interaction, and ultimately their mode of action. ${ }^{5}$ The hydrophilicity-lipophilicity balance can also be controlled by introduction of adequate functional groups in the coordinated ligands. ${ }^{15}$ The cationic nature of these complexes also allowed the exploitation of different counteranions that were revealed to influence the overall cytotoxicity of the compounds as well. ${ }^{5}$ Globally, our studies showed that $\mathrm{N}, \mathrm{N}^{\prime}$ and $\mathrm{N}, \mathrm{O}$ heterocyclic bidentate molecules are the most suitable ligands, together with triphenylphosphane as coligand, and the triflate anion the favored counterion.

The important role of the cyclopentadienyl ligand on the stabilization of the ruthenium(II) center for this structural piano stool arrangement was revealed by electrospray ionization mass spectrometry studies. ${ }^{21}$ Indeed, the fragmentation pathways and energetics of a series of $\left[\mathrm{RuCp}\left(\mathrm{PPh}_{3}\right)\left(\mathrm{N}, \mathrm{N}^{\prime}\right)\right]$ $\left[\mathrm{CF}_{3} \mathrm{SO}_{3}\right]$ compounds always showed the "RuCp" entity at the end of the fragmentation chain, even at high values of energy. ${ }^{21}$ Although the mechanism of action for these complexes is still not completely understood, inductively coupled plasma mass spectrometry results concerning the ruthenium distribution within the several cellular compartments indicate that the interaction with the cell membrane will determinate their mechanism of action. ${ }^{15,22}$

Our continuing studies on the systematic substitutions on the coordinated ligands in the half-sandwich structured compounds based on the "RuCp" scaffold lead us to the recent synthesis of a novel ruthenium methyl-cyclopentadienyl complex, "RuMeCp", bearing a bipyridine perfluorinated ligand (perFluor-bpy). ${ }^{23}$ The strong activity of $\left[\mathrm{Ru}\left(\eta^{5}-\mathrm{MeCp}\right)\left(\mathrm{PPh}_{3}\right)\right.$ (perFluor-bpy)][$\left[\mathrm{CF}_{3} \mathrm{SO}_{3}\right]$ toward colorectal cancer cells stimulated the pursuit of these studies.

Although the chemistry of " $\mathrm{MeCpRu}$ (II)"-based compounds is quite extensive, ${ }^{24-29}$ mainly fuelled by their catalytic properties, the literature is scarce in what concerns mononuclear compounds derived from $\mathrm{MeCpRu}(\mathrm{II})$-containing nitrogen coordinated heteroaromatic ligands. As far as we know, only recently has another compound been reported that presents a nitrogen bidentate ligand, namely $\left[\mathrm{Ru}\left(\eta^{5}-\mathrm{MeCp}\right)\right.$ - $\left({ }^{\mathrm{t}} \mathrm{Bu}_{2}\right.$-im $\left.)(\mathrm{NCMe})\right]\left[\mathrm{PF}_{6}\right],{ }^{30}$ which was prepared from $\left[\mathrm{Ru}\left(\eta^{5}-\right.\right.$ $\left.\mathrm{MeCp})(\mathrm{NCMe})_{3}\right]\left[\mathrm{PF}_{6}\right]$. ${ }^{26}$

The work presented here constitutes a new approach for the synthesis of complexes presenting the general formula $\left[\mathrm{Ru}\left(\eta^{5}\right.\right.$ $\left.\mathrm{MeCp})\left(\mathrm{PPh}_{3}\right)(\mathrm{N}, \mathrm{N})\right]^{+}$using $\left[\mathrm{Ru}\left(\eta^{5}-\mathrm{MeCp}\right)\left(\mathrm{PPh}_{3}\right) \mathrm{Cl}\right]$ as a starting material. $^{23}$

The poor efficacy of cancer chemotherapy often occurs as a result of the intrinsic or acquired resistance to a large range of chemotherapeutic agents, a phenotype called multidrug resistance (MDR). Overexpression of ATP-binding cassette (ABC) cell-membrane transporters has been shown to be responsible for MDR, resulting mostly in an increased drug efflux. The identification of selective inhibitors that block such a mechanism efflux is then pertinent to be explored. ${ }^{31}$ With this aim, the biological studies were focused on the evaluation of compounds' ability to inhibit the most critical proteins involved in MDR belonging to the $\mathrm{ABC}$ family, the P-glycoprotein ( $\mathrm{P}$ $\mathrm{gp}, \mathrm{ABCB} 1$ ), the multidrug resistance proteins 1 and 2 (MRP1 and $\mathrm{MRP} 2, \mathrm{ABCC} 1$ and $\mathrm{ABCC} 2)$ and the breast cancer resistance protein (BCRP, ABCG2).

\section{RESULTS AND DISCUSSION}

Synthesis. A new family of ruthenium-methylcyclopentadienyl complexes incorporating bipyridyl derivatives was isolated as triflate salts for the first time. The complex $\left[\mathrm{Ru}\left(\eta^{5}-\mathrm{MeCp}\right)\left(\mathrm{PPh}_{3}\right)_{2} \mathrm{Cl}\right]$, recently reported by us, ${ }^{23}$ showed to be an adequate starting material to perform the synthesis of a new series of mono cationic ruthenium(II) complexes with general formula $\left[\mathrm{Ru}\left(\eta^{5}-\mathrm{MeCp}\right)\left(\mathrm{PPh}_{3}\right)\left(4,4^{\prime}-\mathrm{R}-2,2^{\prime} \text {-bpy }\right)\right]^{+}$ (Ru1, R = H; Ru2, $\mathrm{R}=\mathrm{CH}_{3} ; \mathbf{R u 3}, \mathrm{R}=\mathrm{CH}_{2} \mathrm{OH}$ ). Sigma coordination of the bidentate $N, N^{\prime}$ chelating ligands to the ruthenium core was achieved in good yields by halide abstraction from the starting material $\left[\mathrm{Ru}\left(\eta^{5}-\mathrm{MeCp}\right)\right.$ $\left.\left(\mathrm{PPh}_{3}\right)_{2} \mathrm{Cl}\right]$ with silver triflate $\left(\mathrm{AgCF}_{3} \mathrm{SO}_{3}\right)$, as presented in Scheme 1. Purification of the organometallic complexes was achieved by slow diffusion recrystallization, at room temperature, affording for all three compounds adequate crystals for single-crystal X-ray diffraction studies.

The formulation and purity of the new family of complexes (Ru1, Ru2, and Ru3) is supported by Fourier transfrom infrared (FTIR); ultraviolet-visible (UV-vis); and ${ }^{1} \mathrm{H},{ }^{13} \mathrm{C}$, and ${ }^{31} \mathrm{P}$ NMR spectroscopic data. Elemental analyses and single-crystal X-ray diffraction corroborated their structures.

NMR Spectroscopy. Table S1 summarizes the ${ }^{1} \mathrm{H}$ NMR data for the new compounds. All resonances were attributed using $1 \mathrm{D}$ and 2D NMR experiments $\left[{ }^{1} \mathrm{H},{ }^{13} \mathrm{C}\right.$, correlation spectroscopy (COSY), heteronuclear multiple quantum coherence (HMQC), and heteronuclear multiple bond coherence $(\mathrm{HMBC})]$ and follow the atom numbering presented in 
Scheme 1. Ru1-Ru3 showed three different resonances in their ${ }^{1} \mathrm{H}$ NMR spectra that were ascribed to the three nonequivalent protons of the methyl-cyclopentadienyl unit. These resonances appeared as a doublet at $\sim 1.65 \mathrm{ppm}$ for the methyl group and as a broad singlet or a multiplet in the range $4.57-4.74 \mathrm{ppm}$ for the two remaining protons of the ring. The splitting detected for the peaks at $\sim 1.65$ and $\sim 4.60 \mathrm{ppm}$ can be addressed to the long-range coupling $\left({ }^{4} \mathrm{~J}_{\mathrm{HH}}\right)$ between the protons $\mathbf{H} \mathbf{1}$ and $\mathbf{H} 3$. In this case, a favorable geometry alignment along the $\mathrm{H}-\mathrm{C}-\mathrm{C}-$ $\mathrm{C}-\mathrm{H} \pi$ chain (mimicking an allylic system) could be obtained and, in all cases, observed with small long-range coupling constants $\left({ }^{4} J_{\mathrm{H} 1-\mathrm{H} 3} \sim 1.6 \mathrm{~Hz}\right) .{ }^{32}$ The evident deshielding on the $\mathrm{H}_{5}$ protons, adjacent to the nitrogen of the bipyridine ring, and a shielding on the $\mathrm{H}_{8}$ protons ligand, observed in all complexes, are clear evidence of successful coordination of the bipyridyl derivative to the metal. Additionally, three resonances appeared as triplet signals $(7.41 \mathrm{ppm}<\delta<7.10 \mathrm{ppm})$ in all ${ }^{1} \mathrm{H}$ NMR complexes' spectra, which were readily attributed to the aromatic protons of the triphenylphosphane coligand.

Characterization of these complexes was completed with APT $-{ }^{13} \mathrm{C}\left\{{ }^{1} \mathrm{H}\right\}$ NMR measurements. The results are in accordance with the previously discussed effects in the ${ }^{1} \mathrm{H}$ NMR analysis. All the detailed spectroscopic data concerning the ${ }^{13} \mathrm{C}$ NMR experiments are in the Experimental Section. The ${ }^{31} \mathrm{P}$ NMR spectra showed a unique sharp singlet resonance at $\sim \delta 51.8$ ppm that was easily attributed to the coordinated triphenylphosphane coligand for the three compounds and is in good agreement with all ${ }^{1} \mathrm{H}$ NMR and ${ }^{13} \mathrm{C}$ NMR collected data.

FTIR Spectroscopy. The analysis of the solid-state FTIR spectra of the organometallic ruthenium methyl-cyclopentadienyl derivatives $\mathbf{R u} \mathbf{1}-\mathbf{R u} 3$ shows the presence of the typical bands expected for the respective $\nu_{\mathrm{CH}}$ stretching of the aromatic rings of methylcyclopentadienyl, bipyridyl, and phosphane ligands in the range $3080-3000 \mathrm{~cm}^{-1}$ and $\sim 2900 \mathrm{~cm}^{-1}$ for the methyl group. Also, the expected bands for $\mathrm{C}=\mathrm{C}$ at $1400-$ $1600 \mathrm{~cm}^{-1}$, together with $\mathrm{C}-\mathrm{C}$ and $\mathrm{C}-\mathrm{H}$ bonding at approximately 1030 and $1380 \mathrm{~cm}^{-1}$, respectively, were observed. The presence of the triflate counterion was revealed in the typical region for this group (ca. $1260 \mathrm{~cm}^{-1}$ ), which agrees with the cationic character of the compounds. The hydroxyl groups of the bpy $\left(\mathrm{CH}_{2} \mathrm{OH}\right)_{2}$ were also found at 3421 $\mathrm{cm}^{-1}$ for complex Ru3.

UV-Vis Spectroscopy. The optical absorption spectra of all ruthenium-cyclopentadienyl complexes were recorded using $1.0 \times 10^{-4}$ to $1.0 \times 10^{-5} \mathrm{M}$ solutions in dichloromethane and dimethyl sulfoxide. Table S2 presents the values obtained for the molar absorptivity coefficient $(\varepsilon)$ and the corresponding wavelength $\left(\lambda_{\max }\right)$, whereas Figure 1 shows the spectrum of compound Ru3, which typifies the general behavior of these compounds. The strong absorption band observed at higher energy, $\sim 290 \mathrm{~nm}$ is commonly attributed to the $\pi-\pi^{*}$ transitions occurring in aromatic ligands. Our density functional theory (DFT) studies (see below) revealed that this intense UV band is mainly an interligand transition involving an electron transfer from a $\pi$ orbital based on the phosphane and on the $\eta^{5}$ $\mathrm{MeCp}$ ligands to the $\pi^{*}$ orbital centered at the bpy coordinated molecules with some contribution of the $\mathrm{Ru}$. A second band observed in all the spectra, occurring in the range of 336-386 $\mathrm{nm}$ can be considered a metal-to-ligand charge-transfer (MLCT) band because it involves a $\pi$ bonding orbital mainly centered on $\mathrm{Ru}$ to a $\pi^{*}$ orbital centered on a bpy-R ligand. The band occurring in the visible part of the spectra, in the range of $420-450 \mathrm{~nm}$, with $\varepsilon$ values from 3.3 to $6.8 \times 10^{3} \mathrm{M}^{-1} \mathrm{~cm}^{-1}$,

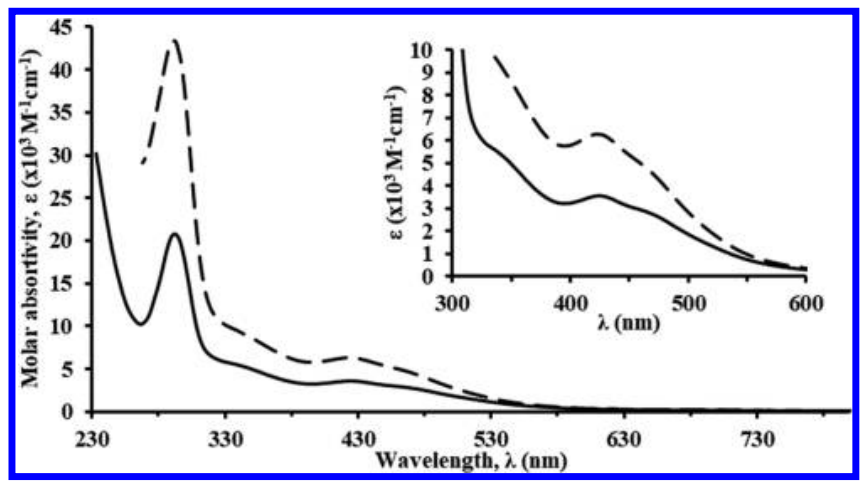

Figure 1. Electronic spectra of complex Ru3 in dichloromethane (solid line) and dimethyl sulfoxide (dashed line) showing the expansion in the range of the CT band.

depending on the solvent, corresponds also to charge-transfer transitions from the $\mathrm{Ru}$ to both $\mathrm{PPh}_{3}$ and bpy- $\mathrm{R}$ ligands. For details, see Table 3 in DFT Studies.

Electrochemical Studies. The electrochemical behavior of these new organometallic ruthenium methyl-cyclopentadienylbased complexes was studied at room temperature by cyclic voltammetry in acetonitrile and dichloromethane solutions.

Table 1 summarizes the electrochemical data for complexes bearing bipyridyl derivatives. Figure 2 shows the behavior of complex Ru2 in acetonitrile.

All the compounds present the typical electrochemical behavior observed for other ruthenium similar compounds, displaying one-electron quasi-reversible coupled redox process in both solvents in the positive potentials range. In acetonitrile, these quasi-reversible processes at $E_{1 / 2}=0.92,0.91$, and $0.89 \mathrm{~V}$, for $\mathbf{R u 1}, \mathbf{R u 2}$, and $\mathbf{R u 3}$, respectively, can be attributed to the $\mathrm{Ru}^{\mathrm{II}} / \mathrm{Ru}{ }^{\mathrm{III}}$ redox couple, in accordance with our earlier results for some ruthenium-cyclopentadienyl analogous. ${ }^{9,15-17}$ At negative potentials, a quasi-reversible redox process $\left(E_{1 / 2}\right.$ between -1.50 and $-1.61 \mathrm{~V}$ ) was also observed for all the complexes, which can be attributed to a bipyridyl ligand-based process.

In dichloromethane, the complexes presented the same general behavior concerning the $\mathrm{Ru}^{\mathrm{II}} / \mathrm{Ru}^{\mathrm{III}}$ redox couple with quasi-reversible processes at $E_{1 / 2}=0.95,0.92$, and $0.90 \mathrm{~V}$, for Ru1, Ru2, and $R \mathbf{u} 3$, respectively. These redox processes are followed by one (Ru1) or two (Ru2 and Ru3) irreversible waves probably attributed to ligand-centered oxidation processes, as was also found for related complexes. ${ }^{9,17}$ The ligand-based redox process found in the negative potentials range in acetonitrile is not observed in dichloromethane.

Concerning the complexes $\mathbf{R u 1}$ and $\mathbf{R u 2}$, the redox potentials found for the $\mathrm{Ru}^{\mathrm{II}} / \mathrm{Ru}^{\mathrm{III}}$ redox pair are slightly lower than the ones found for the related complexes $\left[\mathrm{Ru}\left(\eta^{5}\right.\right.$ $\left.\left.\mathrm{C}_{5} \mathrm{H}_{5}\right)\left(\mathrm{PPh}_{3}\right)(\mathrm{bpy})\right]\left[\mathrm{CF}_{3} \mathrm{SO}_{3}\right]$ and $\left[\mathrm{Ru}\left(\eta^{5}-\mathrm{C}_{5} \mathrm{H}_{5}\right)\left(\mathrm{PPh}_{3}\right)-\right.$ $\left.\left(\mathrm{Me}_{2} \mathrm{bpy}\right)\right]\left[\mathrm{CF}_{3} \mathrm{SO}_{3}\right]\left(E_{1 / 2}=1.05\right.$ and $0.96 \mathrm{~V}$ in dichloromethane, respectively $)^{9,17}$ in the same experimental conditions.

This observation is in accordance with the higher electronic density in the cationic ruthenium(II) center due to the introduction of the electron donor methyl group in the cyclopentadienyl ring. The comparison between the $\mathrm{Ru}^{\mathrm{II}} / \mathrm{Ru}^{\mathrm{III}}$ redox potentials for the three complexes Ru1-Ru3 in both solvents showed that the presence of different substituents on the $p$-position of the bipyridine rings has some influence on the electronic environment of the ruthenium(II) center, making easier the oxidation process. Moreover, the tendency observed 
Table 1. Electrochemical Data for Complexes Ru1-Ru3 ${ }^{a}$

\begin{tabular}{|c|c|c|c|c|c|c|c|c|c|c|}
\hline \multirow[b]{2}{*}{ compound } & \multicolumn{5}{|c|}{ acetonitrile } & \multicolumn{5}{|c|}{ dichloromethane } \\
\hline & $E_{\mathrm{pa}}(\mathrm{V})$ & $E_{\mathrm{pc}}(\mathrm{V})$ & $E_{1 / 2}(\mathrm{~V})$ & $E_{\mathrm{pa}}-E_{\mathrm{pc}}(\mathrm{mV})$ & $I_{c} / I_{a}$ & $E_{\mathrm{pa}}(\mathrm{V})$ & $E_{\mathrm{pc}}(\mathrm{V})$ & $E_{1 / 2}(\mathrm{~V})$ & $E_{\mathrm{pa}}-E_{\mathrm{pc}}(\mathrm{mV})$ & $I_{c} / I_{a}$ \\
\hline \multirow[t]{3}{*}{ Ru1 } & - & - & - & - & - & 1.49 & - & - & - & - \\
\hline & 0.96 & 0.88 & 0.92 & 80 & 1.0 & 0.99 & 0.90 & 0.95 & 90 & 0.6 \\
\hline & -1.55 & -1.61 & -1.58 & 60 & $0.5^{b}$ & - & - & - & - & - \\
\hline \multirow[t]{4}{*}{ Ru2 } & - & - & - & - & - & 1.62 & - & - & - & - \\
\hline & - & - & - & - & - & 1.40 & - & - & - & - \\
\hline & 0.95 & 0.87 & 0.91 & 80 & 0.9 & 0.96 & 0.88 & 0.92 & 80 & 0.8 \\
\hline & -1.58 & -1.65 & -1.61 & 70 & $1.0^{b}$ & - & - & - & - & - \\
\hline \multirow[t]{4}{*}{ Ru3 } & - & - & - & - & - & 1.63 & - & - & - & - \\
\hline & - & - & - & - & - & 1.36 & - & - & - & - \\
\hline & 0.93 & 0.84 & 0.89 & 90 & 0.9 & 0.94 & 0.86 & 0.90 & 80 & 0.9 \\
\hline & -1.46 & -1.55 & -1.51 & 90 & $0.4^{b}$ & - & - & - & - & - \\
\hline
\end{tabular}

${ }^{a}$ All values vs SCE; $v=100 \mathrm{mV} \cdot \mathrm{s}^{-1} \cdot{ }^{b} I_{\mathrm{a}} / I_{\mathrm{c}}$.

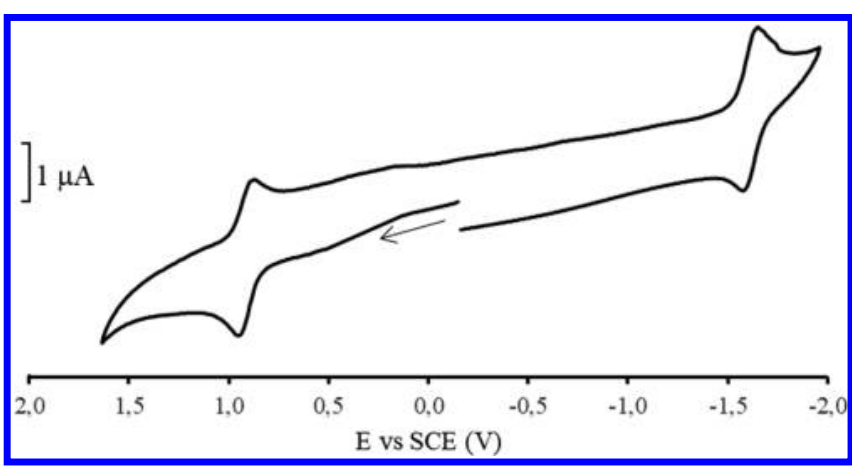

Figure 2. Cyclic voltammogram of $\mathbf{R u} 2$ in acetonitrile (scan rate $=100$ $\left.\mathrm{mV} \cdot \mathrm{s}^{-1}\right)$.

follows the order Ru3 $>\mathbf{R u} \mathbf{2}>\mathbf{R u} \mathbf{1}$ and is in agreement with the highest occupied molecular orbital (HOMO) relative energies (calculated by DFT).

Single-Crystal Structures of $\left[\mathrm{Ru}\left(\eta^{5}-\mathrm{MeCp}\right)\left(\mathrm{PPh}_{3}\right)(\mathrm{bpy}-\right.$ $\mathrm{R})]\left[\mathrm{CF}_{3} \mathrm{SO}_{3}\right]$ Complexes Ru1-Ru3. Ru1, Ru2, and Ru3 crystallize from dichloromethane/ $n$-hexane (Ru1 and Ru2) or dichloromethane/diethyl ether $(\mathbf{R u} 3)$ solutions as red blocks (crystal dimensions $0.43 \times 0.15 \times 0.09 \mathrm{~mm}$ for Rul, $0.28 \times$ $0.17 \times 0.08 \mathrm{~mm}$ for Ru2, and $0.27 \times 0.25 \times 0.14 \mathrm{~mm}$ for Ru3). Figure 3 shows ORTEP representations of Ru1, Ru2, and Ru3. In $\mathbf{R u 2}$, the asymmetric unit contains two ruthenium cation complexes, two $\left(\mathrm{CF}_{3} \mathrm{SO}_{3}\right)^{-}$anions, and two $\mathrm{CH}_{2} \mathrm{Cl}_{2}$ molecules, which are not in symmetric positions with respect to the inversion center of the space group. In the other two compounds, only one ruthenium cation complex and $\left(\mathrm{CF}_{3} \mathrm{SO}_{3}\right)^{-}$anion are present in the asymmetric unit.

In the three molecular structures, the ruthenium center adopts a "piano stool" distribution formed by the ruthenium$\mathrm{MeCp}$ unit bound to one $\mathrm{PPh}_{3}$ and one bpy ligand. The distances for $\mathrm{Ru}-\mathrm{P}$ bonds are in the range of $2.305-2.315 \AA$, and the distances for $\mathrm{Ru}-\mathrm{N}$ bonds are in the range of 2.077$2.092 \AA$ (Table S3). The distances between $\mathrm{Ru}$ and the centroids of the $\pi$-bonded cyclopentadienyl moiety are 1.8340(9) $\AA$ in Ru1, 1.8317(13) $\AA$ and 1.8346(13) $\AA$ for the two complexes present in the asymmetric unit in $\mathbf{R u 2}$, and $1.8284(10) \AA$ in $\mathrm{Ru} 3$ to $\mathrm{Ru}$ centers (ring slippage $0.046 \AA$ in Ru1, 0.049 and $0.057 \AA$ in Ru2, and $0.044 \AA$ in Ru3). The mean value of the $\mathrm{Ru}-\mathrm{C}$ bond distance is $2.198(2) \AA$ for $\mathbf{R u} \mathbf{1}$, 2.196(2) A for $\mathbf{R u} 2$ [only for $\mathrm{Ru}(1)$ metal center], and 2.194(2) A for Ru3. The $\mathrm{Ru}-\mathrm{C}$ distances are longer in the carbon atoms around the methyl group, in the range of 2.20$2.23 \AA$, as in other examples of Cp substitution found in the literature. ${ }^{33}$ Table S3 contains selected bond lengths and angles for the three compounds.

$\mathrm{X}$-ray structure analysis of the structures shows two enantiomers of the cation complexes $\left[\mathrm{Ru}\left(\eta^{5}-\mathrm{MeCp}\right)\left(\mathrm{PPh}_{3}\right)\right.$ $(\mathrm{bpy})]^{+}, \quad\left[\mathrm{Ru}\left(\eta^{5}-\mathrm{MeCp}\right)\left(\mathrm{PPh}_{3}\right)\left(\mathrm{Me}_{2} \mathrm{bpy}\right)\right]^{+}$, and $\left[\mathrm{Ru}\left(\eta^{5}-\right.\right.$ $\left.\left.\mathrm{MeCp})\left(\mathrm{PPh}_{3}\right)\left(\operatorname{bpy}\left(\mathrm{CH}_{2} \mathrm{OH}\right)_{2}\right)\right)\right]^{+}$in the racemic crystals, the chirality being due to a twist of the $\mathrm{PPh}_{3}$ and $\mathrm{Cp}$ units. The

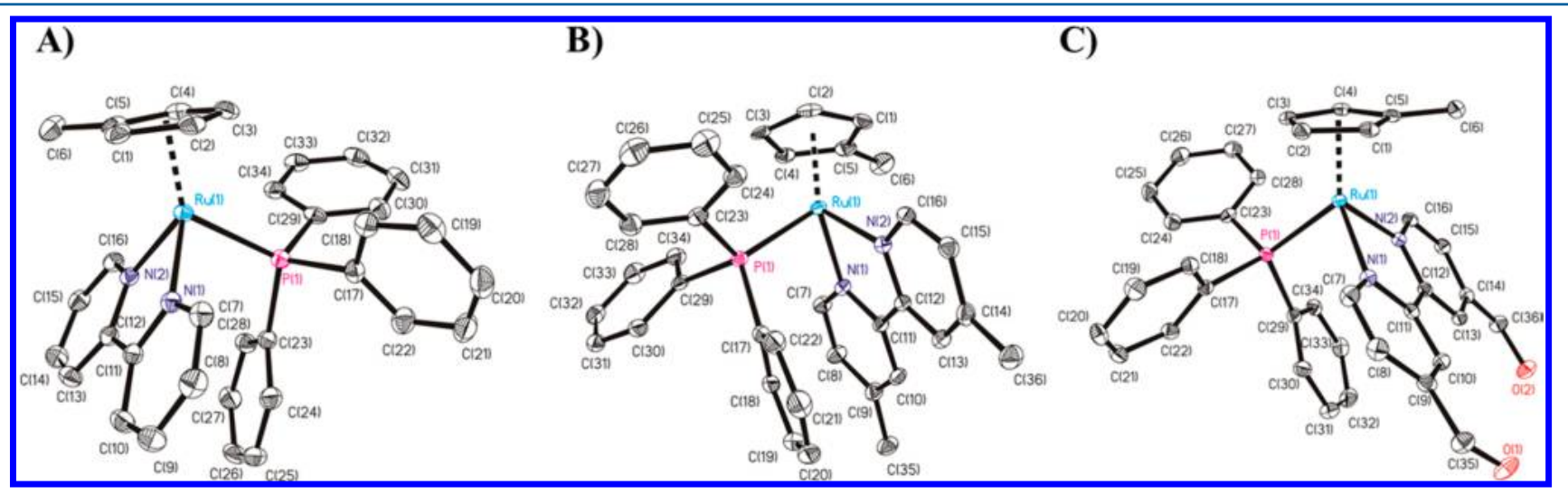

Figure 3. ORTEP for the cation complex in the compounds (A) $\left[\mathrm{Ru}\left(\eta^{5}-\mathrm{MeCp}\right)\left(\mathrm{PPh}_{3}\right)(\mathrm{bpy})\right]\left[\mathrm{CF}_{3} \mathrm{SO}_{3}\right](\mathbf{R u 1}),(\mathrm{B})\left[\mathrm{Ru}\left(\eta^{5}-\mathrm{MeCp}\right)(\mathrm{PPh})-\right.$ $\left(\mathrm{Me}_{2}\right.$ bpy $\left.)\right]\left[\mathrm{CF}_{3} \mathrm{SO}_{3}\right](\mathbf{R u} 2)$, and $\left.(\mathrm{C})\left[\mathrm{Ru}\left(\eta^{5}-\mathrm{MeCp}\right)\left(\mathrm{PPh}_{3}\right)\left(\mathrm{bpy}\left(\mathrm{CH}_{2} \mathrm{OH}\right)_{2}\right)\right)\right]\left[\mathrm{CF}_{3} \mathrm{SO}_{3}\right](\mathbf{R u} 3)$. All the non-hydrogen atoms are presented by their $50 \%$ probability ellipsoids. Hydrogen atoms are omitted for clarity. 
Table 2. Hydrogen Bonds in the Compound $\left.\left[\mathrm{Ru}\left(\eta^{5}-\mathrm{MeCp}\right)\left(\mathrm{PPh}_{3}\right)\left(\mathrm{bpy}\left(\mathrm{CH}_{2} \mathrm{OH}\right)_{2}\right)\right)\right]\left[\mathrm{CF}_{3} \mathrm{SO}_{3}\right]\left(\mathrm{Ru}_{3}\right)$

$\begin{array}{ccccc}\mathrm{D}-\mathrm{H} \cdots \mathrm{A} & d(\mathrm{D}-\mathrm{H}) & d(\mathrm{H} \cdots \mathrm{A}) & d(\mathrm{D} \cdots \mathrm{A}) & (\mathrm{DHA}) \\ \mathrm{O}(1)-\mathrm{H}(1 \mathrm{O}) \cdots \mathrm{O}(3)^{a} & 0.84(3) \AA & 1.92(3) \AA & 2.751(2) \AA & 168(3)^{\circ} \\ \mathrm{O}(2)-\mathrm{H}(2 \mathrm{O}) \cdots \mathrm{O}(5)^{b} & 0.77(3) \AA & 2.02(3) \AA & 2.787(3) \AA & 177(3)^{\circ}\end{array}$

${ }^{a}$ Symmetry transformations used to generate equivalent atoms: $1-x+3 / 2, y+1 / 2,-z+3 / 2 .{ }^{b}$ Symmetry transformations used to generate equivalent atoms: $x, y+1, z$.

Table 3. Experimental and TD-DFT Calculated Optical Data for Complexes Ru1, Ru2, and Ru3 in Dichloromethane

\begin{tabular}{|c|c|c|c|c|c|}
\hline comp. & $\begin{array}{l}\operatorname{exptl} \lambda_{\max } \\
(\mathrm{nm})^{a}\end{array}$ & $\begin{array}{l}\text { calcd } \lambda_{\max } \\
(\mathrm{nm})^{a}\end{array}$ & $\begin{array}{l}\text { vertical exc. } \\
\qquad(\mathrm{nm})^{b}\end{array}$ & major contributions $(\%)^{c}$ & attribution $^{d}$ \\
\hline \multirow[t]{8}{*}{ Ru1 } & - & 512 & $512(0.0002)$ & $\mathrm{H} \rightarrow \mathrm{L}(90)$ & $\mathrm{Ru}(80), \eta^{5}-\mathrm{MeCp}(15), \mathrm{PPh}_{3}(5) \rightarrow$ bpy $(100)$ \\
\hline & $488(\mathrm{sh})$ & 484 & $484(0.0328)$ & $\mathrm{H}-1 \rightarrow \mathrm{L}(74), \mathrm{H}-2 \rightarrow \mathrm{L}(16)$ & $\mathrm{Ru}(76), \eta^{5}-\mathrm{MeCp}(16), \mathrm{PPh}_{3}(8) \rightarrow \operatorname{bpy}(100)$ \\
\hline & $428(3.3)$ & 428 & $432(0.0363)$ & $\mathrm{H}-2 \rightarrow \mathrm{L}(48)$ & $\mathrm{Ru}(57), \eta^{5}-\mathrm{MeCp}(42), \mathrm{PPh}_{3}(1) \rightarrow \operatorname{bpy}(100)$ \\
\hline & & & $416(0.0339)$ & $\mathrm{H}-1 \rightarrow \mathrm{L}+3(47)$ & $\mathrm{Ru}(83), \eta^{5}-\mathrm{MeCp}(17) \rightarrow \mathrm{PPh}_{3}(70), \operatorname{bpy}(30)$ \\
\hline & - & 363 & $363(0.0219)$ & $\mathrm{H}-1 \rightarrow \mathrm{L}+1(89)$ & $\mathrm{Ru}(78), \eta^{5}-\mathrm{MeCp}(21), \mathrm{PPh}_{3}(1) \rightarrow$ bpy $(100)$ \\
\hline & $333(5.5)$ & 332 & $332(0.0343)$ & $\mathrm{H}-2 \rightarrow \mathrm{L}+1(84)$ & $\mathrm{Ru}(84), \eta^{5}-\mathrm{MeCp}(16) \rightarrow \operatorname{bpy}(93), \mathrm{PPh}_{3}(7)$ \\
\hline & $291(21.4)$ & 287 & $287(0.1463)$ & $\mathrm{H}-4 \rightarrow \mathrm{L}(28), \mathrm{H}-1 \rightarrow \mathrm{L}+7(19), \mathrm{H}-1 \rightarrow \mathrm{L}+9(26)$ & $\eta^{5}-\mathrm{MeCp}(74), \operatorname{bpy}(14), \mathrm{PPh}_{3}(12) \rightarrow \mathrm{Ru}(100)$ \\
\hline & & & $286(0.2314)$ & $\mathrm{H}-4 \rightarrow \mathrm{L}(39), \mathrm{H}-1 \rightarrow \mathrm{L}+7(11), \mathrm{H}-1 \rightarrow \mathrm{L}+9(15)$ & $\eta^{5}-\mathrm{MeCp}(79), \mathrm{PPh}_{3}(21) \rightarrow \mathrm{Ru}(89)$, bpy $(11)$ \\
\hline \multirow[t]{7}{*}{ Ru2 } & - & 502 & $502(0.0007)$ & $\mathrm{H} \rightarrow \mathrm{L}(90)$ & $\mathrm{Ru}(80), \eta^{5}-\mathrm{MeCp}(15), \mathrm{PPh}_{3}(5) \rightarrow \operatorname{bpy}(100)$ \\
\hline & $478(\mathrm{sh})$ & 475 & $475(0.0426)$ & $\mathrm{H}-1 \rightarrow \mathrm{L}(78), \mathrm{H}-2 \rightarrow \mathrm{L}(12)$ & $\mathrm{Ru}(74), \eta^{5}-\mathrm{MeCp}(16), \mathrm{PPh}_{3}(10) \rightarrow$ bpy $(100)$ \\
\hline & $423(4.6)$ & 424 & $425(0.0324)$ & $\mathrm{H}-2 \rightarrow \mathrm{L}(67)$ & $\mathrm{Ru}(86), \eta^{5}-\mathrm{MeCp}(14) \rightarrow$ bpy $(97), \mathrm{PPh}_{3}(3)$ \\
\hline & & & $420(0.0288)$ & $\mathrm{H}-1 \rightarrow \mathrm{L}+2(44)$ & $\mathrm{Ru}(80), \eta^{5}-\mathrm{MeCp}(20) \rightarrow \mathrm{PPh}_{3}(81)$, bpy $(19)$ \\
\hline & - & 360 & $360(0.0264)$ & $\mathrm{H}-1 \rightarrow \mathrm{L}+1(85)$ & $\mathrm{Ru}(70), \eta^{5}-\mathrm{MeCp}(27), \mathrm{PPh}_{3}(13) \rightarrow \operatorname{bpy}(100)$ \\
\hline & $336(5.6)$ & 328 & $328(0.0371)$ & $\mathrm{H}-2 \rightarrow \mathrm{L}+1(69), \mathrm{H} \rightarrow \mathrm{L}+4(10)$ & $\mathrm{Ru}(80), \eta^{5}-\mathrm{MeCp}(20) \rightarrow$ bpy $(77), \mathrm{PPh}_{3}(23)$ \\
\hline & $288(24.8)$ & 286 & $286(0.3098)$ & $\mathrm{H}-4 \rightarrow \mathrm{L}(66)$ & $\mathrm{PPh}_{3}(64), \eta^{5}-\mathrm{MeCp}(36) \rightarrow \operatorname{bpy}(93), \mathrm{Ru}(7)$ \\
\hline \multirow[t]{7}{*}{ Ru3 } & - & 512 & $512(0.0007)$ & $\mathrm{H} \rightarrow \mathrm{L}(97)$ & $\mathrm{Ru}(80), \eta^{5}-\mathrm{MeCp}(15), \mathrm{PPh}_{3}(5) \rightarrow \operatorname{bpy}(100)$ \\
\hline & $472(\mathrm{sh})$ & 480 & $480(0.0398)$ & $\mathrm{H}-1 \rightarrow \mathrm{L}(83), \mathrm{H}-2 \rightarrow \mathrm{L}(14)$ & $\mathrm{Ru}(84), \eta^{5}-\mathrm{MeCp}(17), \mathrm{PPh}_{3}(9) \rightarrow \operatorname{bpy}(100)$ \\
\hline & $424(3.6)$ & 428 & $430(0.0630)$ & $\mathrm{H}-2 \rightarrow \mathrm{L}(76), \mathrm{H}-1 \rightarrow \mathrm{L}(11)$ & $\mathrm{Ru}(83), \eta^{5}-\mathrm{MeCp}(15), \mathrm{PPh}_{3}(2) \rightarrow \operatorname{bpy}(100)$ \\
\hline & & & $417(0.0310)$ & $\mathrm{H}-1 \rightarrow \mathrm{L}+2(45)$ & $\mathrm{Ru}(73), \eta^{5}-\mathrm{MeCp}(27) \rightarrow \mathrm{PPh}_{3}(82), \operatorname{bpy}(18)$ \\
\hline & $354(\mathrm{sh})$ & 353 & $353(0.0268)$ & $\mathrm{H}-1 \rightarrow \mathrm{L}+1(87)$ & $\mathrm{Ru}(63), \eta^{5}-\mathrm{MeCp}(34), \mathrm{PPh}_{3}(3) \rightarrow \operatorname{bpy}(100)$ \\
\hline & $332(\mathrm{sh})$ & 324 & $324(0.0320)$ & $\mathrm{H}-2 \rightarrow \mathrm{L}+1(74)$ & $\mathrm{Ru}(73), \eta^{5}-\mathrm{MeCp}(27) \rightarrow$ bpy $(87), \mathrm{PPh}_{3}(13)$ \\
\hline & $292(20.8)$ & 287 & $287(0.4134)$ & $\mathrm{H}-4 \rightarrow \mathrm{L}(72)$ & $\mathrm{PPh}_{3}(67), \eta^{5}-\mathrm{MeCp}(33) \rightarrow \operatorname{bpy}(83), \mathrm{Ru}(17)$ \\
\hline
\end{tabular}

${ }^{a}$ Maxima of the convoluted bands (exptl.: $\varepsilon \times 10^{3} \mathrm{M}^{-1} \mathrm{~cm}^{-1}$ ). ${ }^{b}$ Oscillator strength, $f$, in a.u. in parentheses. ${ }^{c} \mathrm{H}=\mathrm{HOMO}, \mathrm{L}=\mathrm{LUMO}$. ${ }^{d}$ Based on the represented fragments (overall percent of the charge transfer in parentheses).

cation complexes present a mirror plane which contains $\mathrm{P}, \mathrm{Ru}$, and the centroid of $\mathrm{Cp}$ rings (Figure S1). ${ }^{18,34}$ Intermolecular hydrogen bonds are present in $\mathbf{R u} 3$, between the hydroxyl groups and oxygen atoms of $\left(\mathrm{CF}_{3} \mathrm{SO}_{3}\right)^{-}$anions (Table 2).

DFT Studies. To support our spectroscopic data, DFT calculations were performed for all complexes. The optimized structures are shown in Figure S2, and the relevant structural parameters are shown in Table S4. The calculated bond lengths and angles are consistent with crystallographic data. For instance, calculated $\mathrm{X}-\mathrm{C}(\mathrm{X}=\mathrm{C}, \mathrm{N}$, and $\mathrm{Ru}), \mathrm{Ru}-\mathrm{N}$, and $\mathrm{Ru}-\mathrm{P}$ bond lengths show differences up to only $+0.01,+0.05$, and $+0.15 \AA$, respectively, relative to those obtained from X-ray crystal structures. Also, small deviations of the calculated angles, up to $2^{\circ}$, were found.

Donor-acceptor interactions between bpy (or $\mathrm{PPh}_{3}$ ) and $\left[\mathrm{Ru}\left(\eta^{5}-\mathrm{MeCp}\right)\left(\mathrm{PPh}_{3}\right)\right]^{+}\left(\right.$or $\left.\left[\mathrm{Ru}\left(\eta^{5}-\mathrm{MeCp}\right)(\text { bpy })\right]^{+}\right)$fragments were assessed by charge decomposition analysis (CDA) ${ }^{35}$ and are also shown in Table S4. As expected, it can be seen that $\mathrm{L}^{\prime}$ $\rightarrow\left[\mathrm{Ru}\left(\eta^{5}-\mathrm{MeCp}\right)(\mathrm{L})\right]^{+} \sigma$-donation is always greater than $\left[\mathrm{Ru}\left(\eta^{5}-\mathrm{MeCp}\right)(\mathrm{L})\right]^{+} \rightarrow \mathrm{L}^{\prime} \pi$-backdonation for all complexes. The relative weights of the two donor-acceptor components, expressed in terms of the percent of its contribution to the overall interaction, show that the contribution of $\left[\mathrm{Ru}\left(\eta^{5}\right.\right.$ $\left.\mathrm{MeCp})\left(\mathrm{PPh}_{3}\right)\right]^{+} \rightarrow$ bpy $\pi$-backdonation interaction is only moderate $(20-26 \%)$. After the geometry optimizations, the electronic spectra were simulated by means of time-dependent density functional theory (TD-DFT) calculations with the inclusion of solvation effects. Table 3 shows the main vertical optical transitions that contribute to the overall calculated spectra. Experimental data are also included for comparison. As an example, the calculated spectrum of complex Ru3 and its experimental spectrum in dichloromethane are depicted in Figure 4.

Our TD-DFT results predict an intense UV band, together with several low intensity bands in the visible region, in accordance with experimental spectra. The overall agreement between the theoretical and experimental spectra is very good. For example, only small deviations (up to $8 \mathrm{~nm}$ ) between calculated and experimental $\lambda_{\max }$ were found. Representations of the main orbitals contributing to these excitations are depicted in Figure S3. On the basis of the TD-DFT calculations, the experimental intense $\mathrm{UV}$ band, in the range $\lambda=288-292 \mathrm{~nm}$, can be attributed mainly to interligand transitions with some contribution of Ru to $\pi^{*}$, in particular for Ru1. The experimental band at $\lambda=332-336 \mathrm{~nm}$, attributed a $\pi\left(\mathrm{Ru}+\eta^{5}-\mathrm{MeCp}\right)-\pi^{*}(\mathrm{bpy}+$ phosphane $)$ transition, can be viewed as a typical MLCT ( $\mathrm{L}=\mathrm{bpy})$. The experimental band at $\lambda=423-428 \mathrm{~nm}$ is predicted to be a result of a combination of two vertical excitations closer in energy. A $\pi$ bonding orbital mainly centered on $\mathrm{Ru}$ is involved. However, the character of 


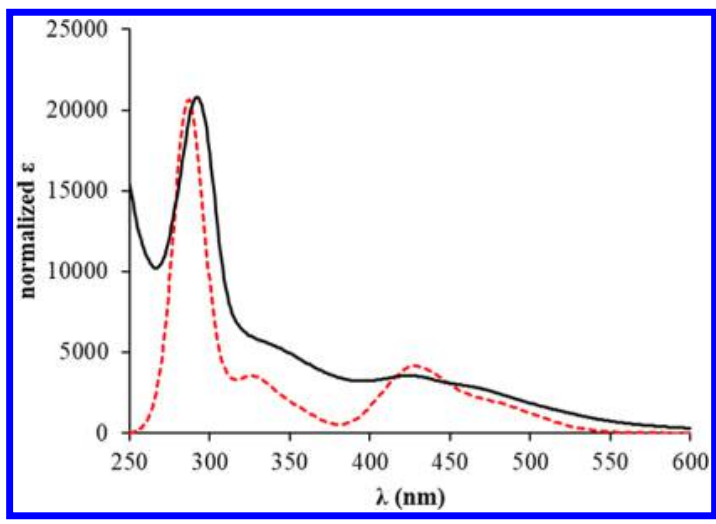

Figure 4. Experimental (black solid line) and calculated (red dashed line) spectra for complex Ru3 in dichloromethane. The intensity of the calculated spectrum was normalized for a better illustration.

$\pi^{*}$ is different: one is clearly centered on the bpy ligand (thus originating a MLCT similar to the one observed for $\lambda=332-$ $336 \mathrm{~nm}$ ), and the other is mainly centered on phosphane. The corresponding electron density difference maps (EDDMs) illustrate this behavior (Figure 5).

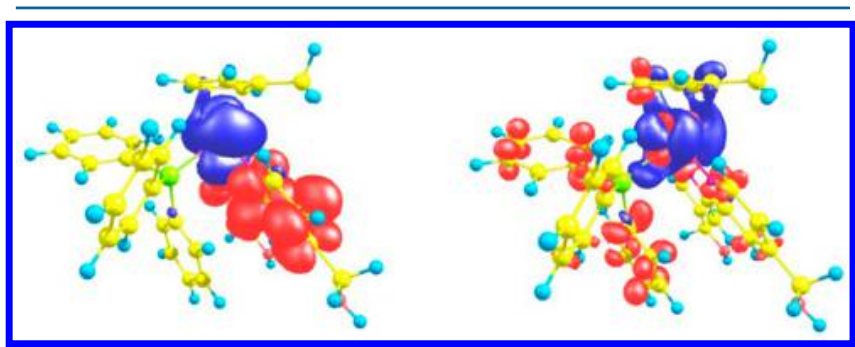

Figure 5. Electron density difference maps (EDDMs) of the vertical transition at $430 \mathrm{~nm}$ (left) and $417 \mathrm{~nm}$ (right) for the complex Ru3. Blue indicates a decrease, and red indicates an increase in electron density; isovalue $=0.001$.

Stability Studies in Aqueous Media. Stability in a physiological like media prior to in vitro evaluation of metallodrugs is a very important issue when assessing the mettallodrugs' biological activity. ${ }^{36}$ In this context, all complexes were tested for their aqueous stability over time using DMSO and culture cellular media DMEM by UV-vis spectroscopy. DMSO was used to dissolve the compounds because they are not completely soluble in the DMEM media.

The samples used in the measurements were protected from light sources and were stored at room temperature between measurements. Only small variations (lower than $6 \%$ over $24 \mathrm{~h}$ ) were observed for all complexes with the bipyridyl derivatives, indicating that the complexes are quite stable over the period tested (Figure S4). Taken together, these results indicate that the compounds are stable in these conditions and the original solid-state three-legged piano stool molecular architecture, bearing the bipyridyl and the phosphane coligands, is kept as such in solution during this period.

Biological Evaluation of the Ru Compounds. We first aimed at evaluating the cytotoxicity of the $\mathrm{Ru}$ compounds and their behavior toward $\mathrm{ABC}$ pumps. Indeed, one major limitation in chemotherapy is the acquired resistance that cancer cells can develop because of the action of MDR ABC efflux transporters that reduce the anticancer drugs' concentration below their threshold of action. ${ }^{37}$ In this regard, the P- gp, MRP1, MRP2, and BCRP (ABCB1, ABCC1, ABCC2, and ABCG2 in terms of the HUGO nomenclature) are the most studied pumps. Figure 6 presents the cytotoxic activity of the complexes Ru1-Ru3 for the NIH3T3 and HEK293 control cells and the same overexpressing of P-gp, MRP1, MRP2, or BCRP.

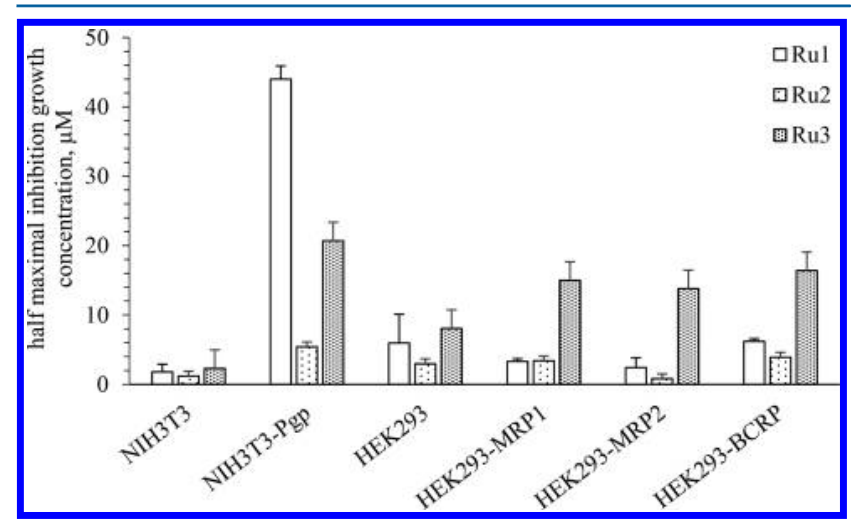

Figure 6. In vitro cytotoxic activity of complexes Ru1-Ru3 in HEK293 or NIH3T3 cell lines expressing or not expressing the ABC MDR transporters. Cells were incubated with various $\mathrm{Ru}$ concentrations for $48 \mathrm{~h}$ at $37^{\circ} \mathrm{C}$, and then cytotoxicity was evaluated by MTT test.

As shown, the cytotoxicity varied with the compounds and slightly with cells, as NIH3T3 cells were more sensible to the $\mathrm{Ru}$ compounds than HEK293 cells. When the cells expressed the MDR pumps, $\mathbf{R u} 2$ exhibited equal toxicity, indicating that it is not a substrate of these efflux pumps. In contrast, Rul was found to be equally toxic for HEK293 cells regardless of the presence or absence of the pumps, while notably, the expression of P-gp in NIH3T3 cells conferred a $24 \times$ resistance, showing that it is substrate of that pump. Finally, Ru3 displayed close cytotoxicity levels for the cell lines and was revealed to be 10 times less toxic for P-gp-expressing cell line and 2 times less toxic for MRP1, MRP2, and BCRP-expressing cells, again showing that it is a substrate of these pumps, although rather poor in the case of the last three pumps.

Because Ru2 was not found to be a substrate of the MDR $A B C$ pumps, we aimed at verifying if it can block their efflux activity. For doing that, we probed the intracellular accumulation of known substrates of each MDR pump using flow cytometry and compared the results to that of reference inhibitors. Results are displayed in Figure 7. Ru2 displayed a poor inhibition capacity of P-gp and BCRP, but in contrast, it was rather efficient in blocking the efflux activity of MRP1 and MRP2.

Uptake of Ru1-Ru3 Complexes in HEK293 WT and HEK 293 BCRP Cell Lines. We then evaluated the uptake of $\mathrm{Ru}$ compounds in cells. To do that, we quantified the $\mathrm{Ru}$ in Ru1-Ru3 penetrating into HEK293 cells using a mass cytometry approach. For this purpose, the flow cytometry was coupled with a microplate reader and an autosampler. The experiment was carried out on HEK293 cells, with or without BCRP expression.

The compounds Ru1 and Ru2 had the highest cell internalization (Figure 8), for both control and BCRPexpressing cells.

Cytotoxicity in Cisplatin-Sensitive and CisplatinResistant Ovarian Cancer Cells. The cytotoxicity of the Ru1-Ru3 complexes was studied by the MTT assay on the 


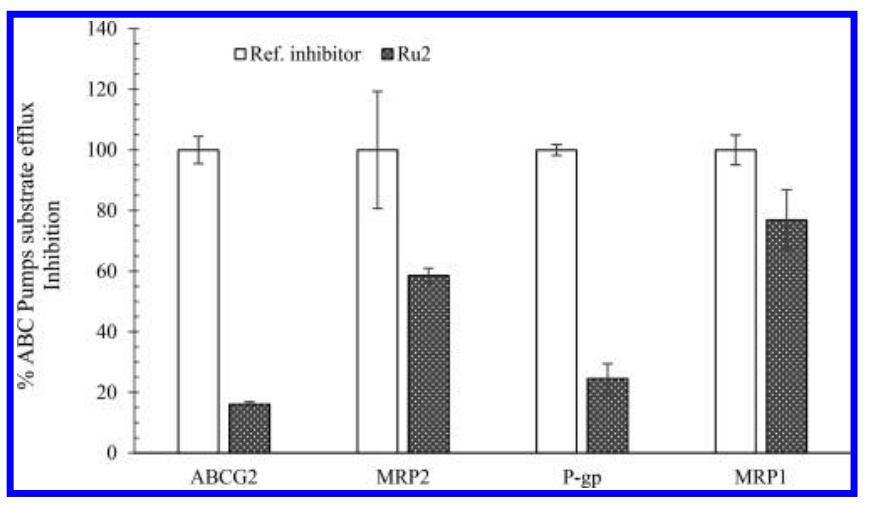

Figure 7. Effect of Ru2 on the intracellular accumulation of MDR ABC pumps substrates. Ru2 was added at $20 \mu \mathrm{M}$ to HEK293 (MRP1, MRP2, and BCRP) or NIH3T3 (P-gp) control and MDR ABC pumps expressing cell lines. The concentration used for substrates was $5 \mu \mathrm{M}$ mitoxantrone for BCRP, $0.5 \mu \mathrm{M}$ rhodamine 123 for P-gp, or $0.2 \mu \mathrm{M}$ calcein AM for MRP1 and MRP2. Reference inhibitors were $1 \mu \mathrm{M}$ Ko143 for BCRP, $5 \mu \mathrm{M}$ GF120918 for P-gp, $35 \mu \mathrm{M}$ verapamil for $\mathrm{MRP} 1$, and $25 \mu \mathrm{M}$ cyclosporine A for MRP2.

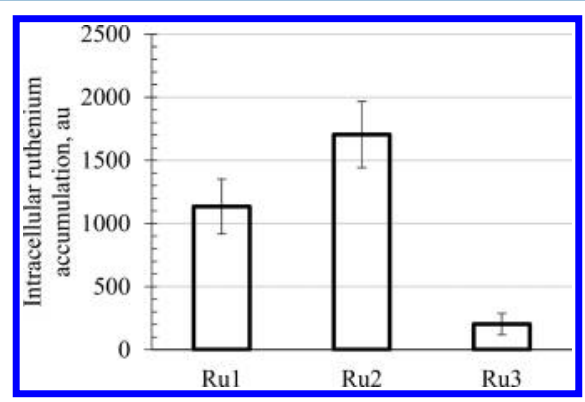

Figure 8. Intracellular quantitation of Ru1-Ru3 compounds in HEK293 cell lines by CyTOF.

epithelial ovarian cancer cells A2780 and its cisplatin-resistant subclone A2780cisR. The A2780 cell line was established from tumor tissue from an untreated patient, while the A2780CisR cell line was developed by chronic exposure of the parent cell line to increasing concentrations of cisplatin. Cells were incubated with each compound in serial concentrations within the range of $0.01-100 \mu \mathrm{M}$ for $24 \mathrm{~h}$. The dose-response curves of cellular viability were obtained (Figure S5), and the $\mathrm{IC}_{50}$ values calculated for Ru1-Ru3 are presented in Figure 9 and Table S5. Cisplatin (CDDP) was also introduced for comparison.

As can be seen, Ru1-Ru3 compounds exhibited high cytotoxicity against the ovarian cells tested, displaying inhibition growths 5-35 times better than cisplatin in the A2780 cells and 10-120 times better in the cisplatin-resistant cells A2780cisR. Ru2 displayed the highest efficacy in both cases, being 3-10 times more efficient than Ru3 or Ru1. This higher efficiency may be due to the more pronounced hydrophobic character of the methyl substituents in Ru2 versus the hydrogen atom or hydroxymethyl group for Rul and Ru3, respectively. None of the free ligands [bpy, $\mathrm{Me}_{2} \mathrm{bpy}$, or bpy $\left.\left(\mathrm{CH}_{2} \mathrm{OH}\right)_{2}\right]$ displayed cytotoxicity against the tested cells within the concentration range studied $\left(\mathrm{IC}_{50}>100 \mu \mathrm{M}\right)$.

When (indirectly) compared to previous compounds synthesized in our group, namely, the compounds with general formula $\left[\mathrm{Ru}\left(\eta^{5}-\mathrm{C}_{5} \mathrm{H}_{5}\right)\left(4,4^{\prime}-\mathrm{R}-2,2^{\prime} \text {-bpy }\right)\left(\mathrm{PPh}_{3}\right)\right]^{+}$, with $\mathrm{R}=\mathrm{H}$ $\left[\mathrm{IC}_{50} \mathrm{~A} 2780(72 \mathrm{~h})=0.14 \pm 0.01 \mu \mathrm{M}\right]^{11}$ and $\mathrm{R}=-\mathrm{CH}_{3}\left[\mathrm{IC}_{50}\right.$ $\mathrm{A} 2780(72 \mathrm{~h})=0.1 \pm 0.01 \mu \mathrm{M}],{ }^{9}$ we can state that the new

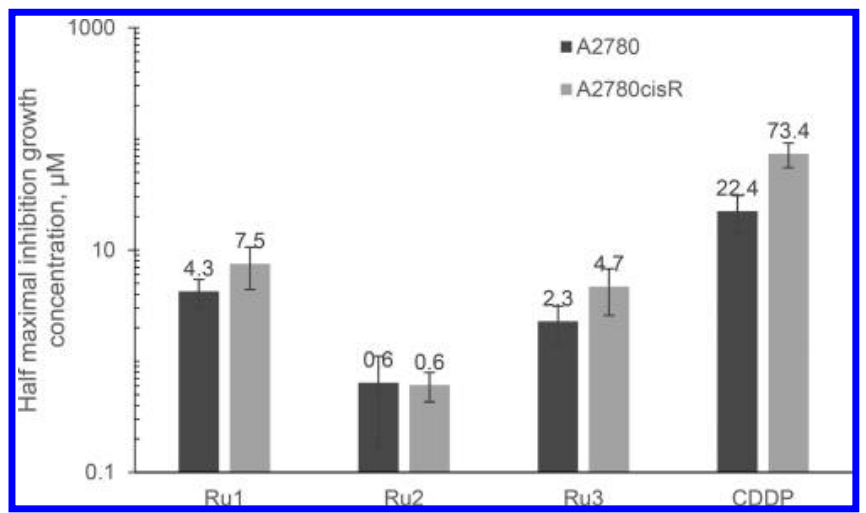

Figure 9. Cytotoxicity of $\mathbf{R u}$ compounds and CDDP to cisplatinsensitive A2780 and cisplatin-resistant A2780cisR ovarian cancer cell lines.

analogues with the methyl group in the $\mathrm{Cp}$ ring have retained the high cytotoxic activity even at shorter incubation times.

\section{CONCLUSIONS}

Three new ruthenium(II) compounds with the general formula $\left[\mathrm{Ru}\left(\eta^{5}-\mathrm{MeCp}\right)\left(\mathrm{PPh}_{3}\right)\left(4,4^{\prime}-\mathrm{R}-2,2^{\prime}-\mathrm{bpy}\right)\right]^{+}(\mathbf{R u} 1, \mathrm{R}=\mathrm{H} ; \mathbf{R u} 2, \mathrm{R}$ $\left.=\mathrm{CH}_{3} ; \mathrm{Ru} 3, \mathrm{R}=\mathrm{CH}_{2} \mathrm{OH}\right)$ have been described here for the first time. Spectroscopic data and DFT analysis showed that $\pi$ backdonation from the bipyridine and phosphane ligands is present, even if the $\sigma$-donation is always larger. The higher electronic density in the cationic ruthenium(II) center due to the introduction of the electron donor methyl group in the cyclopentadienyl can be observed by the lower redox potential found for the $\mathrm{Ru}^{\mathrm{II}} / \mathrm{Ru}^{\mathrm{III}}$ redox pair, comparatively to their related complexes without the methyl group. ${ }^{9,17}$ The substituent groups on the $p$-position of the bipyridine rings also exert some influence on the ruthenium oxidation process that is easier for $\mathbf{R u} \mathbf{3}>\mathbf{R u} \mathbf{2}>\mathbf{R u} \mathbf{1}$, which is in agreement with the HOMO relative energies calculated by DFT. The three compounds crystallize in centrosymmetric space groups ( Ru1 and Ru3 in the monoclinic $P 2_{1} / c$ and $P 2_{1} / n$, respectively; Ru2 in the triclinic $\mathrm{P} \overline{1})$ as enantiomers.

All compounds presented adequate stability for the biological assays. We first aimed at evaluating their cytotoxicity and behavior toward $\mathrm{ABC}$ pumps, which are responsible for acquired resistance to treatment, one of the major limitations in chemotherapy. Although Rul and Ru3 are (poor) substrates of MDR pumps, Ru2 is not a MDR substrate but, notably, displays inhibitory properties for MRP1 and MRP2 pumps. In addition, all the compounds of this series were shown to be potential cytotoxic agents as they show a high cytotoxic profile in the human ovarian cancer cells tested with $\mathrm{IC}_{50}$ values surpassing up to 120 times the metallodrug cisplatin under the same experimental conditions. Ru1-Ru3 are also more cytotoxic than other $\mathrm{Ru}(\mathrm{II})$-arene related compounds from the literature. ${ }^{38-40}$

Further studies will be performed to evaluate the underlying mechanisms of action for these promising chemotherapeutic agents, in particular for $\mathbf{R u} \mathbf{2}$ that combines the cytotoxic effect with the ability to overcome MDR.

\section{EXPERIMENTAL SECTION}

General Procedures. All reactions and manipulations were performed under nitrogen atmosphere using Schlenk techniques. All solvents used were dried and freshly distilled under nitrogen prior to use, using standard methods. ${ }^{41} \mathrm{H},{ }^{13} \mathrm{C}$, and ${ }^{31} \mathrm{P}$ NMR spectra were 
recorded on a Bruker Avance 400 spectrometer at probe temperature using commercially available deuterated solvents. ${ }^{1} \mathrm{H}$ and ${ }^{13} \mathrm{C}$ chemical shifts $(\mathrm{s}=$ singlet; $\mathrm{d}=$ duplet; $\mathrm{t}=$ triplet; $\mathrm{q}=$ quartet; $\mathrm{m}=$ multiplet; comp $=$ complex $)$ are reported in parts per million $(\mathrm{ppm})$ downfield from internal standard $\mathrm{Me}_{4} \mathrm{Si}$, and the ${ }^{31} \mathrm{P}$ NMR spectra are reported in ppm downfield from external standard, $85 \% \mathrm{H}_{3} \mathrm{PO}_{4}$. Coupling constants are reported in $\mathrm{Hz}$. All assignments were attributed using APT $-{ }^{13} \mathrm{C}\{1 \mathrm{H}\}$ or ${ }^{13} \mathrm{C}\left\{{ }^{1} \mathrm{H}\right\}, \mathrm{COSY}, \mathrm{HMBC}$, and HMQC NMR techniques. Infrared spectra were recorded on $\mathrm{KBr}$ pellets using a Mattson Satellite FTIR spectrophotometer, and only relevant bands are cited in the text. Electronic spectra were obtained at room temperature on a Jasco V-560 spectrometer from solutions of $10^{-4}$ $10^{-6} \mathrm{M}$ in quartz cuvettes (1 cm optical path). Elemental analyses were performed at Laboratório de Análises, at Instituto Superior Técnico, using a Fisons Instruments EA1 108 system. Data acquisition, integration, and handling were performed using a PC with the software package EAGER-200 (Carlo Erba Instruments). $\left[\mathrm{Ru}\left(\eta^{5}-\mathrm{MeCp}\right)\right.$ $\left.\left(\mathrm{PPh}_{3}\right)_{2} \mathrm{Cl}\right]$ starting material was obtained following a literature protocol. ${ }^{23}$

Synthesis. To a stirred and degassed solution of $\left[\mathrm{Ru}\left(\eta^{5}\right.\right.$ $\left.\mathrm{MeCp})\left(\mathrm{PPh}_{3}\right)_{2} \mathrm{Cl}\right](0.250 \mathrm{~g}, 0.34 \mathrm{mmol})$ in dichloromethane (40 $\mathrm{mL})$ was added $\mathrm{AgCF}_{3} \mathrm{SO}_{3}(0.096 \mathrm{~g}, 0.37 \mathrm{mmol})$. The resulting mixture was stirred for $1 \mathrm{~h}$ at room temperature followed by the addition of $4,4^{\prime}-\mathrm{R}-2,2^{\prime}$-bipyridine $\left(0.37 \mathrm{mmol}\right.$ of $2,2^{\prime}$-bipyridine for Ru1, $0.38 \mathrm{mmol}$ of 4,4'-dimethyl-2,2'-bipyridine for Ru2, and 0.38 mmol of 4,4'-dihydroxymethyl-2,2'-bipyridine for Ru3). After $8 \mathrm{~h}$ in reflux, the orange color turned red (Ru1) or dark orange (Ru2 and Ru3). The reaction mixture was cooled to room temperature and filtered, and the solvent was removed under vacuum. Crystals were obtained after recrystallization from dichloromethane $/ n$-hexane at room temperature for $\mathbf{R u 1}$ and $\mathbf{R u 2}$. For $\mathbf{R u} 3$, the residue was recrystallized once from dichloromethane $/ n$-hexane and once from tetrahydrofuran/ $n$-hexane; dark orange crystals were obtained after room-temperature recrystallization from dichloromethane/diethyl ether.

$\left[\mathrm{Ru}\left(\eta^{5}-\mathrm{MeCp}\right)\left(\mathrm{PPh}_{3}\right)(\mathrm{bpy})\right]\left[\mathrm{CF}_{3} \mathrm{SO}_{3}\right]$ (Ru1). Yield: $52 \%$; red crystals. ${ }^{1} \mathrm{H}$ NMR $\left[\left(\mathrm{CD}_{3}\right)_{2} \mathrm{CO}, \mathrm{Me}_{4} \mathrm{Si}, \delta(\mathrm{ppm})\right]: 9.46\left(\mathrm{~d}, 2 \mathrm{H},{ }^{3} J_{\mathrm{HH}}=5.6, \mathrm{H}_{5}\right)$, $8.19\left(\mathrm{~d}, 2 \mathrm{H},{ }^{3} \mathrm{~J}_{\mathrm{HH}}=8.0, \mathrm{H}_{8}\right), 7.90\left(\mathrm{t}, 2 \mathrm{H},{ }^{3} \mathrm{~J}_{\mathrm{HH}}=7.6, \mathrm{H}_{7}\right), 7.39(\mathrm{~m}, 5 \mathrm{H}$, $\left.\mathrm{H}_{p} \mathrm{PPh}_{3}+\mathrm{H}_{6}\right), 7.31\left(\mathrm{t}, 6 \mathrm{H},{ }^{3} J_{\mathrm{HH}}=7.6, \mathrm{H}_{m} \mathrm{PPh}_{3}\right), 7.10\left(\mathrm{t}, 6 \mathrm{H},{ }^{3} J_{\mathrm{HH}}=\right.$ 9.6, $\left.\mathrm{H}_{0} \mathrm{PPh}_{3}\right), 4.74\left(\mathrm{~s}, 2 \mathrm{H}, \mathrm{H}_{4}\right), 4.64\left(\mathrm{~m}, 2 \mathrm{H},{ }^{4} J_{\mathrm{HH}}=1.6, \mathrm{H}_{3}\right), 1.65(\mathrm{~d}$, $\left.3 \mathrm{H},{ }^{4} J_{\mathrm{HH}}=1.6, \mathrm{H}_{1}\right) \cdot{ }^{13} \mathrm{C} \mathrm{NMR}\left[\left(\mathrm{CD}_{3}\right)_{2} \mathrm{CO}, \delta(\mathrm{ppm})\right]: 156.8\left({ }^{3} J_{\mathrm{CP}}=2\right.$, $\left.\mathrm{C}_{5}\right), 156.7\left(\mathrm{C}_{9}\right), 137.0\left(\mathrm{C}_{7}\right), 133.9\left({ }^{2} J_{\mathrm{CP}}=11, \mathrm{CH}_{0} \mathrm{PPh}_{3}\right), 132.7\left({ }^{1} J_{\mathrm{CP}}=\right.$ $\left.42, \mathrm{C}_{\mathrm{q}} \mathrm{PPh}_{3}\right), 131.0\left({ }^{4} J_{\mathrm{CP}}=2, \mathrm{CH}_{p} \mathrm{PPh}_{3}\right), 129.5\left({ }^{3} J_{\mathrm{PC}}=10, \mathrm{CH}_{\mathrm{m}} \mathrm{PPh}_{3}\right)$, $126.4\left(\mathrm{C}_{6}\right), 124.1\left(\mathrm{C}_{8}\right), 103.5\left(\mathrm{C}_{2}\right), 77.1\left(\mathrm{C}_{3}+\mathrm{C}_{4}\right), 11.7\left(\mathrm{~d}, \mathrm{C}_{1}\right) .{ }^{31} \mathrm{P}$ NMR $\left[\left(\mathrm{CD}_{3}\right)_{2} \mathrm{CO}, \delta(\mathrm{ppm})\right]: 51.8\left[\mathrm{~s}, \mathrm{PPh}_{3}\right]$. FTIR $\left[\mathrm{KBr}, \mathrm{cm}^{-1}\right]: 3055$ $\mathrm{cm}^{-1}\left(v_{\mathrm{C}-\mathrm{H}}\right.$, aromatic, MeCp), 2922-2855 cm $\mathrm{cm}^{-1}\left(v_{\mathrm{C}-\mathrm{H}}, \mathrm{MeCp}\right), 1435$ $\mathrm{cm}^{-1}\left(v_{\mathrm{C}=\mathrm{C}}\right.$, phenyl rings, $\left.\mathrm{MeC} \mathbf{p}\right), 1273 \mathrm{~cm}^{-1}\left(v \mathrm{CF}_{3} \mathrm{SO}_{3}\right.$ counterion). UV-vis [DMSO, $\left.\lambda_{\max }(\mathrm{nm})\left(\varepsilon \times 10^{3} \mathrm{M}^{-1} \mathrm{~cm}^{-1}\right)\right]: 293(21.5), 355$ (Sh), 424 (3.5), 477 (Sh). UV-vis $\left[\mathrm{CH}_{2} \mathrm{Cl}_{2}, \lambda_{\max }(\mathrm{nm})\left(\varepsilon \times 10^{3}\right.\right.$ $\mathrm{M}^{-1} \mathrm{~cm}^{-1}$ )]: 291 (21.4), 333 (5.5), 428 (3.3), 488 (Sh). Elemental analysis. Calcd for $\mathrm{C}_{35} \mathrm{H}_{30} \mathrm{~F}_{3} \mathrm{~N}_{2} \mathrm{O}_{3} \mathrm{PRuS} \cdot 1 / 10 \mathrm{CH}_{2} \mathrm{Cl}_{2}$ : C, 55.8; $\mathrm{H}, 4.0$; $\mathrm{N}, 3.7 ; \mathrm{S}, 4.2$. Found: C, 55.7; H, 4.0; N, 3.7; S, 4.0.

$\left[R u\left(\eta^{5}-\mathrm{MeCp}\right)\left(\mathrm{PPh}_{3}\right)\left(\mathrm{Me}_{2} b p y\right)\right]\left[\mathrm{CF}_{3} \mathrm{SO}_{3}\right]$ (Ru2). Yield: 67\%; dark orange crystals. ${ }^{1} \mathrm{H}$ NMR $\left[\left(\mathrm{CD}_{3}\right)_{2} \mathrm{CO}, \mathrm{Me}_{4} \mathrm{Si}, \delta(\mathrm{ppm})\right]: 9.24(\mathrm{~d}, 2 \mathrm{H}$, $\left.{ }^{3} J_{\mathrm{HH}}=6.0, \mathrm{H}_{5}\right), 8.04\left(\mathrm{~s}, 2 \mathrm{H}, \mathrm{H}_{8}\right), 7.43\left(\mathrm{t}, 3 \mathrm{H},{ }^{3} \mathrm{~J}_{\mathrm{HH}}=6.0, \mathrm{H}_{\mathrm{p}} \mathrm{PPh}_{3}\right)$, $7.22\left(\mathrm{~d}, 2 \mathrm{H},{ }^{3} \mathrm{~J}_{\mathrm{HH}}=6.8, \mathrm{H}_{6}\right), 7.33\left(\mathrm{t}, 6 \mathrm{H},{ }^{3} J_{\mathrm{HH}}=7.2, \mathrm{H}_{m} \mathrm{PPh}_{3}\right), 7.12(\mathrm{t}$, $\left.6 \mathrm{H},{ }^{3} J_{\mathrm{HH}}=8.0, \mathrm{H}_{0} \mathrm{PPh}_{3}\right), 4.68\left(\mathrm{~s}, 2 \mathrm{H}, \mathrm{H}_{4}\right), 4.57\left(\mathrm{~m}, 2 \mathrm{H},{ }^{4} \mathrm{~J}_{\mathrm{HH}}=1.6\right.$, $\left.\mathrm{H}_{3}\right), 2.46\left(\mathrm{~s}, 6 \mathrm{H}, \mathrm{H}_{10}\right), 1.65\left(\mathrm{~d}, 3 \mathrm{H},{ }^{4} J_{\mathrm{HH}}=1.6, \mathrm{H}_{1}\right) . \mathrm{APT}-{ }^{13} \mathrm{C}\left\{{ }^{1} \mathrm{H}\right\}$ NMR $\left[\left(\mathrm{CD}_{3}\right)_{2} \mathrm{CO}, \delta(\mathrm{ppm})\right]: 156.3\left(\mathrm{C}_{9}\right), 155.9\left({ }^{3} J_{\mathrm{CP}}=1.7, \mathrm{C}_{5}\right), 149.2$ $\left(\mathrm{C}_{7}\right), 133.8\left({ }^{2} J_{\mathrm{CP}}=11, \mathrm{CH}_{o} \mathrm{PPh}_{3}\right), 133.0\left({ }^{1} J_{\mathrm{CP}}=40, \mathrm{C}_{q} \mathrm{PPh}_{3}\right), 130.8$ $\left({ }^{4} J_{\mathrm{CP}}=2, \mathrm{CH}_{p} \mathrm{PPh}_{3}\right), 129.3\left({ }^{3} J_{\mathrm{CP}}=10, \mathrm{CH}_{m} \mathrm{PPh}_{3}\right), 127.3\left(\mathrm{C}_{6}\right), 124.6$ $\left(\mathrm{C}_{8}\right), 103.0\left(\mathrm{C}_{2}\right), 76.5\left(\mathrm{C}_{4}\right), 76.4\left(\mathrm{C}_{3}\right), 20.8\left(\mathrm{C}_{10}\right), 11.7\left(\mathrm{~d}, \mathrm{C}_{1}\right) \cdot{ }^{31} \mathrm{P}$ NMR $\left[\left(\mathrm{CD}_{3}\right)_{2} \mathrm{CO}, \delta(\mathrm{ppm})\right]: 51.8\left[\mathrm{~s}, \mathrm{PPh}_{3}\right]$. FTIR $\left[\mathrm{KBr}, \mathrm{cm}^{-1}\right]$ : $3073-3055 \mathrm{~cm}^{-1}\left(v_{\mathrm{C}-\mathrm{H}}\right.$ phenyl, MeCp), $2922 \mathrm{~cm}^{-1}\left(v_{\mathrm{C}-\mathrm{H}} \mathrm{MeCp}\right)$, $1440\left(v_{\mathrm{C}=\mathrm{C}}\right.$, phenyl rings, $\left.\mathrm{MeCp}\right), 1260 \mathrm{~cm}^{-1}\left(v \mathrm{CF}_{3} \mathrm{SO}_{3}\right.$ counterion). UV-vis [DMSO, $\left.\lambda_{\max }(\mathrm{nm})\left(\varepsilon \times 10^{3} / \mathrm{M}^{-1} \mathrm{~cm}^{-1}\right)\right]: 291(26.7), 333$ (Sh), 418 (4.8), 479 (Sh). UV-vis $\left[\mathrm{CH}_{2} \mathrm{Cl}_{2}, \lambda_{\max }(\mathrm{nm})\left(\varepsilon \times 10^{3}\right.\right.$ $\mathrm{M}^{-1} \mathrm{~cm}^{-1}$ )]: 288 (24.8), 336 (5.6), 423 (4.6), 478 (Sh). Elemental analysis. Calcd for $\mathrm{C}_{37} \mathrm{H}_{34} \mathrm{~F}_{3} \mathrm{~N}_{2} \mathrm{O}_{3} \mathrm{PRuS} \cdot{ }_{1}{ }_{3} \mathrm{CH}_{2} \mathrm{Cl}_{2}$ : C, 55.7; H, 4.2; N, 3.4; S, 4.2. Found: C, 55.5; H, 4.2; N, 3.4; S, 3.7.
$\left.\left[\mathrm{Ru}\left(\eta^{5}-\mathrm{MeCp}\right)\left(\mathrm{PPh}_{3}\right)\left(\mathrm{bpy}\left(\mathrm{CH}_{2} \mathrm{OH}\right)_{2}\right)\right)\right]\left[\mathrm{CF}_{3} \mathrm{SO}_{3}\right] \quad(\mathrm{Ru} 3)$. Yield: $58 \%$; dark orange crystals. ${ }^{1} \mathrm{H}$ NMR $\left[\left(\mathrm{CD}_{3}\right)_{2} \mathrm{CO}, \mathrm{Me}_{4} \mathrm{Si}, \delta(\mathrm{ppm})\right]: 9.34$ (d, $\left.2 \mathrm{H},{ }^{3} \mathrm{~J}_{\mathrm{HH}}=5.6, \mathrm{H}_{5}\right), 8.10\left(\mathrm{~s}, 2 \mathrm{H}, \mathrm{H}_{8}\right), 7.40\left(\mathrm{t}, 3 \mathrm{H},{ }^{3} J_{\mathrm{HH}}=6.8, \mathrm{H}_{\mathrm{p}} \mathrm{PPh}_{3}\right)$, $7.36\left(\mathrm{~d}, 2 \mathrm{H},{ }^{3} J_{\mathrm{HH}}=6.0, \mathrm{H}_{6}\right), 7.31\left(\mathrm{t}, 6 \mathrm{H},{ }^{3} J_{\mathrm{HH}}=7.2, \mathrm{H}_{m} \mathrm{PPh}_{3}\right), 7.11(\mathrm{t}$, $\left.6 \mathrm{H},{ }^{3} \mathrm{~J}_{\mathrm{HH}}=8.8, \mathrm{H}_{0} \mathrm{PPh}_{3}\right), 4.79\left(\mathrm{~m}, 4 \mathrm{H}, \mathrm{H}_{10}\right), 4.71\left(\mathrm{~s}, 2 \mathrm{H}, \mathrm{H}_{4}\right), 4.60(\mathrm{~m}$, $\left.2 \mathrm{H},{ }^{4} \mathrm{~J}_{\mathrm{HH}}=1.6, \mathrm{H}_{3}\right), 1.66\left(\mathrm{~s}, 3 \mathrm{H},{ }^{4} J_{\mathrm{HH}}=1.6, \mathrm{H}_{1}\right) . \mathrm{APT}-{ }^{13} \mathrm{C}\left\{{ }^{1} \mathrm{H}\right\} \mathrm{NMR}$ $\left[\left(\mathrm{CD}_{3}\right)_{2} \mathrm{CO}, \delta(\mathrm{ppm})\right]: 156.3\left(\mathrm{C}_{9}\right), 156.1\left({ }^{3} J_{\mathrm{CP}}=1.9, \mathrm{C}_{5}\right), 153.7\left(\mathrm{C}_{7}\right)$, $133.8\left({ }^{2} J_{\mathrm{PC}}=11, \mathrm{CH}_{o} \mathrm{PPh}_{3}\right), 132.9\left({ }^{1} J_{\mathrm{PC}}=40, \mathrm{C}_{q} \mathrm{PPh}_{3}\right), 130.8\left({ }^{4} J_{\mathrm{PC}}=\right.$ 2, $\left.\mathrm{CH}_{p} \mathrm{PPh}_{3}\right), 129.3\left({ }^{3} \mathrm{JC}_{\mathrm{PC}}=9, \mathrm{CH}_{\mathrm{m}} \mathrm{PPh}_{3}\right), 123.6\left(\mathrm{C}_{6}\right), 120.8\left(\mathrm{C}_{8}\right)$, $103.0\left(\mathrm{C}_{2}\right), 76.7\left(\mathrm{C}_{4}\right), 76.6\left(\mathrm{C}_{3}\right), 62.5\left(\mathrm{C}_{10}\right), 11.7\left(\mathrm{C}_{1}\right) .{ }^{31} \mathrm{P}$ NMR $\left[\left(\mathrm{CD}_{3}\right)_{2} \mathrm{CO}, \delta(\mathrm{ppm})\right]: 51.9\left[\mathrm{~s}, \mathrm{PPh}_{3}\right]$. FTIR $\left[\mathrm{KBr}, \mathrm{cm}^{-1}\right]: 3429 \mathrm{~cm}^{-1}$ $\left(v_{\mathrm{O}-\mathrm{H}}\right), 3084-3065 \mathrm{~cm}^{-1}\left(v_{\mathrm{C}-\mathrm{H}}\right.$, phenyl, MeCp); 2922-2855 $\mathrm{cm}^{-1}$ $\left(v_{\mathrm{C}-\mathrm{H}} \mathrm{MeCp}\right), 1440\left(v_{\mathrm{C}=\mathrm{C}}\right.$, phenyl rings, $\left.\mathrm{MeCp}\right), 1256 \mathrm{~cm}^{-1}$ ( $v \mathrm{CF}_{3} \mathrm{SO}_{3}$ counterion), $1225 \mathrm{~cm}^{-1}\left(v_{\mathrm{C}-\mathrm{O}}\right)$. UV-vis [DMSO, $\lambda_{\max }$ $\left.(\mathrm{nm})\left(\varepsilon \times 10^{3} \mathrm{M}^{-1} \mathrm{~cm}^{-1}\right)\right]: 290(54.0), 350(\mathrm{Sh}), 422(6.8), 480(\mathrm{Sh})$. UV-vis $\left[\mathrm{CH}_{2} \mathrm{Cl}_{2}, \lambda_{\max }(\mathrm{nm})\left(\varepsilon \times 10^{3} \mathrm{M}^{-1} \mathrm{~cm}^{-1}\right)\right]: 292$ (20.8), 332 (Sh), 354 (Sh), 424 (3.6), 472 (Sh). Elemental analysis. Calcd for $\mathrm{C}_{37} \mathrm{H}_{34} \mathrm{~F}_{3} \mathrm{~N}_{2} \mathrm{O}_{5} \mathrm{PRuS} \cdot 1 / 2 \mathrm{CH}_{2} \mathrm{Cl}_{2}$ : C, 53.0; H, 4.2; N, 3.3; S, 3.8. Found: C, 53.0; H, 4.0; N, 3.4; S, 4.0.

X-ray Crystal Structure Determination. Three-dimensional Xray data for $\left[\mathrm{Ru}\left(\eta^{5}-\mathrm{MeCp}\right)\left(\mathrm{PPh}_{3}\right)(\mathrm{bpy})\right]\left[\mathrm{CF}_{3} \mathrm{SO}_{3}\right](\mathrm{Ru} \mathbf{1}),\left[\mathrm{Ru}\left(\eta^{5}-\right.\right.$ $\mathrm{MeCp})\left(\mathrm{PPh}_{3}\right)\left(\mathrm{Me}_{2}\right.$ bpy $\left.)\right]\left[\mathrm{CF}_{3} \mathrm{SO}_{3}\right] \cdot \mathrm{CH}_{2} \mathrm{Cl}_{2}$ (Ru2), and $\left[\mathrm{Ru}\left(\eta^{5}-\right.\right.$ $\left.\left.\mathrm{MeCp})\left(\mathrm{PPh}_{3}\right)\left(\operatorname{bpy}\left(\mathrm{CH}_{2} \mathrm{OH}\right)_{2}\right)\right)\right]\left[\mathrm{CF}_{3} \mathrm{SO}_{3}\right](\mathrm{Ru} 3)$ were collected on a Bruker SMART Apex CCD diffractometer at 100(2) K using a graphite monochromator and Mo K $\alpha$ radiation $(\lambda=0.71073 \AA)$ by the $\phi-\omega$ scan method. Reflections were measured from a hemisphere of data collected of frames each covering $0.3^{\circ}$ in $\omega$. A total of 68350 , 152 907, and 71274 reflections for Ru1, Ru2, and Ru3, respectively, were measured, all of which were corrected for Lorentz and polarization effects and for absorption by semiempirical methods based on symmetry-equivalent and repeated reflections. Of the total, 5806 for Ru1, 13003 for Ru2, and 6383 for Ru3 independent reflections exceeded the significance level $|F| / \sigma(|F|)>4.0$. After data collection, in each case a multiscan absorption correction (SADABS $)^{42}$ was applied, and the structures were solved by direct methods and refined by full matrix least-squares on $F^{2}$ data using the SHELX suite of programs. ${ }^{43}$ The non-hydrogen atoms were refined with anisotropic thermal parameters in all cases. Hydrogen atoms were included in calculation positions and refined in the riding mode, except for $\mathrm{O} 1$ and $\mathrm{O} 2$ atoms in Ru3, which were located in difference Fourier map and left to refine freely. A final difference Fourier map showed no residual density outside, 0.548 and $-0.500 \mathrm{e} \cdot \AA^{-3}$ for Rul and 0.430 and -0.522 e. $\AA^{-3}$ for Ru3, except for compound Ru2, which presents a residual density outside next to the $\mathrm{CF}_{3} \mathrm{SO}_{3}$ ion and around solvent molecules, which was not refined: 2.165 and $-0.957 \mathrm{e} \cdot \AA^{-3}$. Weighting schemes $w=1 /\left[\sigma^{2}\left(F_{\mathrm{o}}^{2}\right)+(0.036700 P)^{2}+2.273600 P\right]$ for Ru1, $w=1 /$ $\left[\sigma^{2}\left(F_{\mathrm{o}}^{2}\right)+(0.062900 P)^{2}+4.819400 P\right]$ for Ru2, and $w=1 /\left[\sigma^{2}\left(F_{\mathrm{o}}^{2}\right)+\right.$ $\left.(0.039300 P)^{2}+2.445400 P\right]$ for Ru3, where $P=\left(\left|F_{\mathrm{o}}\right|^{2}+2\left|F_{\mathrm{c}}\right|^{2}\right) / 3$, were used in the latter stages of refinement. CCDC numbers 18201371820139 contain the supplementary crystallographic data for Rul, Ru2, and Ru3. These data can be obtained free of charge via http:// www.ccdc.cam.ac.uk/conts/retrieving.html. Crystal data and details of the data collection and refinement for the new compounds are collected in Table S6.

DFT Studies. Ground geometries were obtained by density functional theory (DFT) from optimizations using the hybrid metaGGA Thrular's M06 functional, ${ }^{44,45}$ as implemented in Gaussian 09, ${ }^{46}$ with the LANL2DZ effective core potential basis set ${ }^{47,48}$ for $\mathrm{P}$ and $\mathrm{Ru}$ and the $6-31 G(d, p)$ basis set for all the other atoms. Frequency analysis was subsequently performed in the gas-phase without any symmetry constrains, confirming each optimized geometry as an energy minimum by the absence of imaginary frequencies. Charge decomposition analysis (CDA) was performed, at the same theory level, using the QMforge software. ${ }^{49}$ The TD-DFT method was used to calculate the low-lying excited states of the complexes using the M06 functional with the SMD ${ }^{50}$ solvent model using the $6-31+G(d, p)$ basis set together with the LANL2DZ effective core potential basis set for the $\mathrm{P}$ and $\mathrm{Ru}$ atoms. The equations were solved for the lowest 50 excited states, and the simulated absorption bands were obtained by convolution of Gaussian functions centered at the calculated excitation 
energies using the GaussSum 3.0 software. ${ }^{51}$ The Chemcraft 1.7 (http://www.chemcraftprog.com) program was used for the visualization of the remaining computed results.

Electrochemical Experiments. The redox potentials for all complexes were measured by cyclic voltammetry using an EG\&G Princeton Applied Research Model 273A potentiostat-galvanostat monitored with a personal computer loaded with Electrochemistry PowerSuite v2.51 software from Princeton Applied Research. Cyclic voltammograms were obtained using $1 \mathrm{mM}$ of complexes in anhydrous acetonitrile or dichloromethane solutions containing tetrabutylammonium hexafluorophosphate ( 0.1 or $0.2 \mathrm{M}$, respectively) as supporting electrolyte. A three-electrode configuration electrochemical cell was used with a platinum-disk working electrode $(1.0 \mathrm{~mm}$ diameter) probed by a Luggin capillary connected to a silver-wire pseudoreference electrode and a platinum wire auxiliary electrode. All measurements were done at room temperature, and the solutions were deaerated with nitrogen atmosphere before use. All the potentials reported were measured against the ferrocene/ferrocenium redox couple as internal standard and normally quoted relative to SCE (using the ferrocenium/ferrocene redox couple $E_{1 / 2}=0.46$ or $0.40 \mathrm{~V}$ versus SCE for dichloromethane or acetonitrile, respectively). Reagent grade solvents were dried, purified by standard procedures, and distilled under nitrogen atmosphere before use.

Stability Studies in DMSO and DMSO/DMEM. For the stability studies, all the complexes were dissolved in DMSO or 5\% DMSO/ 95\% DMEM at ca. $0.5-1 \times 10^{-4} \mathrm{M}$ for Ru1-Ru3, and their electronic spectra were recorded in the range allowed by the solvents at set time intervals.

Biological Evaluation. Cell Lines and Culture Conditions. To evaluate the selectivity of our compounds on other $A B C$ transporters, we used the NIH3T3 parental cell line and NIH3T3/ABCB1 drugresistant cell line transfected with human MDR1/A-G185, purchased from American Type Culture Collection (Manassas, VA) and used as described previously. ${ }^{52}$ HEK293 (Human embryonic kidney cell) was used to express ABCG2 $2^{53}$ and Flp-In-293 cells to express ABCC1 and $\mathrm{ABCC} 2$ genes as described previously ${ }^{54}$ transfected by electroporation using a Neon Transfection System (ThermoFisher scientific) with pcDNA5-FRT-ABCC2. Human A2780 (cisplatin-sensitive) and A2780cis (cisplatin-resistant) ovarian cancer cell lines were purchased from Sigma-Aldrich.

Cells were grown at $37{ }^{\circ} \mathrm{C}$ in $5 \% \mathrm{CO}_{2}$ in Dulbecco's modified Eagles's medium (DMEM high glucose) (PAA, GE Healthcare Life Sciences, Velizy-Villacoublay, France) supplemented with $10 \%$ fetal bovine serum (FBS, PAA, GE Healthcare Life sciences, VelizyVillacoublay, France), 1\% penicillin/streptomycin (PAA, GE Healthcare Life Sciences, Velizy-Villacoublay, France), with selection for the MRP1, MRP2, BCRP for HEK293, and P-gp-transfected cell line for NIH3T3. The A2780/A2780cisR cells were cultured in RPMI 1640 medium with $10 \%$ FBS and $1 \%$ antibiotics, HEPES, and L-glutamine.

All the cells were adherent in monolayers and, upon confluence, were washed with phosphate buffer saline (PBS) $1 \times$ and harvested by digestion with trypsin $0.05 \%(\mathrm{v} / \mathrm{v})$. Trypsin was inactivated by adding fresh complete culture media to the culture flask. Cells were then suspended and transferred into new, sterile culture flasks or seeded in sterile test plates for the different assays.

All cells were manipulated under aseptic conditions in a flow chamber.

Compound Dilution and Storage. All compounds were dissolved in DMSO and divided in aliquots of $10 \mu \mathrm{L}$ each. They were store at $-20{ }^{\circ} \mathrm{C}$ until use.

Compound Cytotoxicity Evaluated by MTT Assay. Cell survival was studied by using the MTT (3-(4,5-2-yl)-2,5-ditetrazolium bromide) colorimetric assay. Cells were plated in 96-well sterile plates at a density to ensure exponential growth of untreated control samples throughout the experiment, $10^{4}$ cells per well with $200 \mu \mathrm{L}$ of medium. For $24 \mathrm{~h}$, cells were allowed to settle followed by the addition of dilution series of the test compounds. Complexes were solubilized in DMSO/DMEM, with a maximum of $0.5 \%$ of DMSO per concentration, in a range of $0-200 \mu \mathrm{M}$. After continuous exposure to the compounds for $48 \mathrm{~h}$, at $37{ }^{\circ} \mathrm{C}$ with $5 \%$ of $\mathrm{CO}_{2}$, the media were removed, and cells were incubated with MTT solution in PBS (0.5 $\mathrm{mg} / \mathrm{mL}$ ) at the same conditions. After $4 \mathrm{~h}$, the yellow solution was carefully removed, and the purple formazan crystals formed inside the cells were dissolved with DMSO through shaking. The cellular viability was evaluated by measurement of the absorbance at $570 \mathrm{~nm}$ by using a plate spectrophotometer, and this was corrected with the absorbance measured at $690 \mathrm{~nm}$.

For A2780 and A2780cisR cell lines, cells were plated in 96-well sterile plates in complete RPMI medium at a density to ensure exponential growth of the controls (cells with no treatment) throughout the assay. Cells $\left(10^{4}\right.$ cells $/ 200 \mu \mathrm{L}$ medium $)$ were allowed to settle for $24 \mathrm{~h}$ before the addition of dilution series of the test compounds. Complexes were first solubilized in DMSO and then in medium with a maximum of $1 \%$ of DMSO for the higher concentration, in a range of $0.01-100 \mu \mathrm{M}$. After continuous exposure to the compounds for $24 \mathrm{~h}$, at $37^{\circ} \mathrm{C}$ with $5 \%$ of $\mathrm{CO}_{2}$, the medium was removed, and cells were incubated with MTT solution in PBS (0.5 $\mathrm{mg} / \mathrm{mL}$ ). After $3 \mathrm{~h}$, the yellow solution was carefully removed, and the purple formazan crystals formed inside the cells were dissolved with DMSO through shaking. The cellular viability was evaluated by measurement of the absorbance at $570 \mathrm{~nm}$ using a plate spectrophotometer.

Flow Cytometry. Cells were seeded at a density of $10^{5}$ cells/well into 24-well culture plates. After a $24 \mathrm{~h}$ incubation period, they were exposed to different concentrations of compounds and substrates for $30 \mathrm{~min}$ at $37{ }^{\circ} \mathrm{C}, 5 \% \mathrm{CO}_{2}$. After treatment, cells were washed with phosphate buffer saline (PBS) and detached from the plates with trypsin. Then the media was neutralized with PBS, resuspended, and transferred to cytometer tubes. The samples were kept in ice until the analysis (for a maximum of $2 \mathrm{~h}$ ) in a FACSCalibur cytometer (BD Biosciences, San Jose, CA) and a BD LSR-II system.

Ru1-Ru3 Uptake Evaluation in Single Cells by Mass Cytometry. Cells were seeded in 6-well plates for $48 \mathrm{~h}$ to reach a density of $\sim 10^{6}$ cells $/ \mathrm{mL}$. Cells were treated for $15 \mathrm{~min}$ with $20 \mu \mathrm{M}$ compounds and then washed with PBS, trypsinized for 5 min, washed, and transferred to microcentrifuge tubes. Cells were then centrifuged at $300 \mathrm{~g}$ for 5 min; the supernatant was discarded, and cells were incubated with 20 $\mu \mathrm{M} \mathbf{R u 1 - R u 3}$ for $5 \mathrm{~min}$. Cells were centrifuged again, washed with Dulbecco's phosphate-buffered saline (DPBS), and fixed overnight in 1 $\mathrm{mL}$ of $4 \%$ paraformaldehyde. The next day, the supernatant was discarded, and we added $0.25 \mu \mathrm{M}$ iridium to label the DNA (for 45 min). Then, we carefully washed the cells with MaxPar water and DPBS to discard traces of metals. After one last centrifugation, cells were then injected into a mass cytometer (cyTOF II mass cytometer, DVS Sciences Inc.). Cells were atomized and ionized in a hightemperature inductively coupled plasma. The atomic composition of each cell (including metal tags) was then measured by time-of-flight mass spectrometry, generating distinct mass spectra of each cell. The mass cytometer can measure heavy elements naturally present or introduced into a cell, such as iodine and $\mathrm{Ru}$.

\section{ASSOCIATED CONTENT}

\section{Supporting Information}

The Supporting Information is available free of charge on the ACS Publications website at DOI: 10.1021/acs.inorgchem.8b00358.

${ }^{1} \mathrm{H}$ NMR and optical spectral data; X-ray data (bond lengths and angles, view along $\mathrm{Ru}-\mathrm{P}$ edge of the enantiomers, crystal data, and structure refinement); DFT details (optimized geometries, calculated structural data, estimated CDA donations and $\pi$-backdonations, selected orbitals, and Cartesian coordinates for the optimized structures); stability curves; cell viability assays; dose-response curves (PDF)

\section{Accession Codes}

CCDC 1820137-1820139 contain the supplementary crystallographic data for this paper. These data can be obtained free of 
charge via www.ccdc.cam.ac.uk/data_request/cif, or by emailing data_request@ccdc.cam.ac.uk, or by contacting The Cambridge Crystallographic Data Centre, 12 Union Road, Cambridge CB2 1EZ, UK; fax: +44 1223336033.

\section{AUTHOR INFORMATION}

\section{Corresponding Authors}

*E-mail: amvalente@fc.ul.pt.

*E-mail: pierre.falson@ibcp.fr.

\section{ORCID}

Andreia Valente: 0000-0002-3370-208X

\section{Author Contributions}

OL.C.-R., R.G.T., and P.G. contributed equally to this work.

\section{Notes}

The authors declare no competing financial interest.

\section{ACKNOWLEDGMENTS}

This work was financed by the Portuguese Foundation for Science and Technology (Fundação para a Ciência e Tecnologia, FCT) within the scope of projects UID/QUI/ 00100/2013 and UID/Multi/04349/2013. A.V. acknowledges the Investigator FCT2013 Initiative for the project IF/01302/ 2013 (acknowledging FCT, as well as POPH and FSE European Social Fund). L.C.-R. thanks FCT for her Ph.D. Grant (SFRH/BD/100515/2014). P.G. was funded by the Erasmus + Program and a fellowship received from the French National Research Agency, ANR-13-BSV5-0001-01 (to Dr. Pierre Falson).

\section{REFERENCES}

(1) Alessio, E.; Guo, Z. Metal Anticancer Complexes - Activity, Mechanism of Action, Future Perspectives. Eur. I. Inorg. Chem. 2017, 2017 (12), 1539-1540.

(2) Velders, A. H.; Bergamo, A.; Alessio, E.; Zangrando, E.; Haasnoot, J. G.; Casarsa, C.; Cocchietto, M.; Zorzet, S.; Sava, G. Synthesis and Chemical-Pharmacological Characterization of the Antimetastatic NAMI-A-Type $\mathrm{Ru}(\mathrm{III})$ Complexes (Hdmtp)[trans$\mathrm{RuCl}$ 4(dmso-S)(dmtp)], (Na)[trans-RuCl4(dmso-S)(dmtp)], and [Mer-RuCl3(H2O)(dmso-S)(dmtp)] (Dmtp = 5,7-Dimethyl[1,2,4]triazolo[1,5-A]. I. Med. Chem. 2004, 47, 1110-1121.

(3) Silvestru, C. Book Reviews. Appl. Organomet. Chem. 1994, 8, 499-500.

(4) Allardyce, B. C. S.; Dyson, P. J. Ruthenium in Medicine: Current Clinical Uses and Future Prospects. Platinum Met. Rev. 2001, 45, 6269.

(5) Morais, T. S.; Valente, A.; Tomaz, A. I.; Marques, F.; Garcia, M. H. Tracking Antitumor Metallodrugs: Promising Agents with the $\mathrm{Ru}(\mathrm{II})$ - and $\mathrm{Fe}(\mathrm{II})$-Cyclopentadienyl Scaffolds. Future Med. Chem. 2016, 8, 527-544.

(6) Komeda, S.; Casini, A. Next-Generation Anticancer Metallodrugs. Curr. Top. Med. Chem. 2012, 12, 219-235.

(7) Morais, T. S.; Santos, F. C.; Corte-Real, L.; Garcia, M. H. Exploring the Effect of the Ligand Design on the Interactions between $[\mathrm{Ru}(\eta 5-\mathrm{C} 5 \mathrm{H} 5)(\mathrm{PPh} 3)(\mathrm{N}, \mathrm{O})][\mathrm{CF} 3 \mathrm{SO} 3]$ Complexes and Human Serum Albumin. I. Inorg. Biochem. 2013, 129, 94-101.

(8) Pilon, A.; Gírio, P.; Nogueira, G.; Avecilla, F.; Adams, H.; Lorenzo, J.; Garcia, M. H.; Valente, A. New Iron Cyclopentadienyl Complexes Bearing Different Phosphane Co -Ligands: Structural Factors vs. Cytotoxicity. I. Organomet. Chem. 2017, 852, 34-42.

(9) Morais, T. S.; Santos, F.; Côrte-Real, L.; Marques, F.; Robalo, M. P.; Madeira, P. J. A.; Garcia, M. H. Biological Activity and Cellular Uptake of $[\mathrm{Ru}(\eta 5-\mathrm{C} 5 \mathrm{H} 5)(\mathrm{PPh} 3)(\mathrm{Me} 2 \mathrm{bpy})][\mathrm{CF} 3 \mathrm{SO} 3]$ Complex. I. Inorg. Biochem. 2013, 122, 8-17.

(10) Gonçalves, A. C.; Morais, T. S.; Robalo, M. P.; Marques, F.; Avecilla, F.; Matos, C. P.; Santos, I.; Tomaz, A. I.; Garcia, M. H.
Important Cytotoxicity of Novel iron(II) Cyclopentadienyl Complexes with Imidazole Based Ligands. I. Inorg. Biochem. 2013, 129, 1-8.

(11) Tomaz, A. I.; Jakusch, T.; Morais, T. S.; Marques, F.; de Almeida, R. F. M.; Mendes, F.; Enyedy, E. A.; Santos, I.; Pessoa, J. C.; Kiss, T.; Garcia, M. H. $\left[\operatorname{RuII}\left(\eta^{5}-\mathrm{C}_{5} \mathrm{H}_{5}\right)(\text { bipy })\left(\mathrm{PPh}_{3}\right)\right]^{+}$, a Promising Large Spectrum Antitumor Agent: Cytotoxic Activity and Interaction with Human Serum Albumin. I. Inorg. Biochem. 2012, 117, 261-269.

(12) Côrte-Real, L.; Mendes, F.; Coimbra, J.; Morais, T. S.; Tomaz, A. I.; Valente, A.; Garcia, M. H.; Santos, I.; Bicho, M.; Marques, F. Anticancer Activity of Structurally Related ruthenium(II) Cyclopentadienyl Complexes. JBIC, I. Biol. Inorg. Chem. 2014, 19, 853-867.

(13) Mendes, N.; Tortosa, F.; Valente, A.; Marques, F.; Matos, A.; Morais, T. S.; Tomaz, A. I.; Gärtner, F.; Garcia, M. H. In Vivo Performance of a Ruthenium-Cyclopentadienyl Compound in an Orthotopic Triple Negative Breast Cancer Model. Anti-Cancer Agents Med. Chem. 2017, 17, 126-136.

(14) Helena Garcia, M.; Morais, T. S.; Florindo, P.; Piedade, M. F. M.; Moreno, V.; Ciudad, C.; Noe, V. Inhibition of Cancer Cell Growth by ruthenium(II) Cyclopentadienyl Derivative Complexes with Heteroaromatic Ligands. I. Inorg. Biochem. 2009, 103, 354-361.

(15) Morais, T. S.; Santos, F. C.; Jorge, T. F.; Côrte-Real, L.; Madeira, P. J. A.; Marques, F.; Robalo, M. P.; Matos, A.; Santos, I.; Garcia, M. H. New Water-Soluble ruthenium(II) Cytotoxic Complex: Biological Activity and Cellular Distribution. I. Inorg. Biochem. 2014, 130, $1-14$.

(16) Morais, T. S.; Silva, T. J. L.; Marques, F.; Robalo, M. P.; Avecilla, F.; Madeira, P. J. A.; Mendes, P. J. G.; Santos, I.; Garcia, M. H. Synthesis of Organometallic ruthenium(II) Complexes with Strong Activity against Several Human Cancer Cell Lines. I. Inorg. Biochem. 2012, 114, 65-74.

(17) Moreno, V.; Font-Bardia, M.; Calvet, T.; Lorenzo, J.; Avilés, F. X.; Garcia, M. H.; Morais, T. S.; Valente, A.; Robalo, M. P. DNA Interaction and Cytotoxicity Studies of New ruthenium(II) Cyclopentadienyl Derivative Complexes Containing Heteroaromatic Ligands. I. Inorg. Biochem. 2011, 105, 241-249.

(18) Côrte-Real, L.; Paula Robalo, M.; Marques, F.; Nogueira, G.; Avecilla, F.; Silva, T. J. L.; Santos, F. C.; Isabel Tomaz, A.; Helena Garcia, M.; Valente, A. The Key Role of Coligands in Novel ruthenium(II)-Cyclopentadienyl Bipyridine Derivatives: Ranging from Non-Cytotoxic to Highly Cytotoxic Compounds. I. Inorg. Biochem. 2015, 150, 148-159.

(19) Valente, A.; Santos, A. M.; Côrte-Real, L.; Robalo, M. P.; Moreno, V.; Font-Bardia, M.; Calvet, T.; Lorenzo, J.; Garcia, M. H. New iron(II) Cyclopentadienyl Derivative Complexes: Synthesis and Antitumor Activity against Human Leukemia Cancer Cells. L. Organomet. Chem. 2014, 756, 52-60.

(20) Valente, A.; Garcia, M. H.; Marques, F.; Miao, Y.; Rousseau, C.; Zinck, P. First Polymer "ruthenium-Cyclopentadienyl" complex as Potential Anticancer Agent. L. Inorg. Biochem. 2013, 127, 79-81.

(21) Madeira, P. J. A.; Morais, T. S.; Silva, T. J. L.; Florindo, P.; Garcia, M. H. Gas-Phase Behaviour of $\mathrm{Ru}(\mathrm{II})$ CyclopentadienylDerived Complexes with N-Coordinated Ligands by Electrospray Ionization Mass Spectrometry: Fragmentation Pathways and Energetics. Rapid Commun. Mass Spectrom. 2012, 26, 1675-1686.

(22) Côrte-Real, L.; Matos, A. P.; Alho, I.; Morais, T. S.; Tomaz, A. I.; Garcia, M. H.; Santos, I.; Bicho, M. P.; Marques, F. Cellular Uptake Mechanisms of an Antitumor Ruthenium Compound: The Endosomal/lysosomal System as a Target for Anticancer Metal-Based Drugs. Microsc. Microanal. 2013, 19, 1122-1130.

(23) Teixeira, R. G.; Brás, A. R.; Côrte-Real, L.; Tatikonda, R.; Sanches, A.; Robalo, M. P.; Avecilla, F.; Moreira, T.; Garcia, M. H.; Haukka, M.; Preto, A.; Valente, A. Novel Ruthenium Methylcyclopentadienyl Complex Bearing a Bipyridine Perfluorinated Ligand Shows Strong Activity towards Colorectal Cancer Cells. Eur. I. Med. Chem. 2018, 143, 503-514.

(24) Brunner, H.; Tsuno, T.; Bodensteiner, M.; Gärtner, S.; Miyahara, C.; Ito, S.; Kurosawa, T.; Koyama, K. Co-Crystallization of Half-Sandwich $\left(R_{{ }_{M}}, R_{C}\right) /\left(S_{M}, R_{C}\right)$ Diastereomers in Single Crystals. Eur. I. Inorg. Chem. 2016, 2016, 5400-5400. 
(25) Guan, H.; Iimura, M.; Magee, M. P.; Norton, J. R.; Zhu, G. Ruthenium-Catalyzed Ionic Hydrogenation of Iminium Cations. Scope and Mechanism. I. Am. Chem. Soc. 2005, 127, 7805-7814.

(26) Duraczyńska, D.; Nelson, J. H. Diphenylvinylphosphine (DPVP) Complexes Containing the ( 5 -MeC $5 \mathrm{H} 4$ ) Ru (II) Moiety: Synthesis, Characterization and Reactions. Dalt. Trans. 2003, 449457.

(27) Fuller, R. O.; Griffith, C. S.; Koutsantonis, G. A.; Lapere, K. M.; Skelton, B. W.; Spackman, M. A.; White, A. H.; Wild, D. A. Seemingly Simple Group 8 Cyclopentadienyl Dicarbonyl Metal Halides: From Little Things, Interesting Things Grow. CrystEngComm 2012, 14, 812-818.

(28) Hoke, J. B.; Hollis, L. S.; Stern, E. W. Catalytic Asymmetric Hydrogenation of Beta-Ketoesters Using New Binap Complexes of Ruthenium. I. Organomet. Chem. 1993, 455, 193-196.

(29) Duraczyńska, D.; Nelson, J. H. Phosphaallyl Complexes of $\mathrm{Ru}$ (II) Derived from Dicyclohexylvinylphosphine (DCVP). Dalton Trans. 2005, 92-103.

(30) Smarun, A. V.; Shahreel, W.; Pramono, S.; Koo, S. Y.; Tan, L. Y.; Ganguly, R.; Vidović, D. Influence of Increasing Steric Demand on Isomerization of Terminal Alkenes Catalyzed by Bifunctional Ruthenium Complexes. I. Organomet. Chem. 2017, 834, 1-9.

(31) Ozben, T. Mechanisms and Strategies to Overcome Multiple Drug Resistance in Cancer. FEBS Lett. 2006, 580, 2903-2909.

(32) Pavia, D. L.; Lampman, G. M.; Kriz, G. S. Introduction to Spectroscopy, 3rd ed.; Thomson Learning, Inc.: 2001; p 579.

(33) Knowles, D. R. T.; Adams, H.; Maitlis, P. M. Ring-Methyl Activation in Pentamethylcyclopentadienyl Complexes. 8. Introduction of Organic Functionalities at Substituted Tetramethylcyclopentadienyl Complexes of Ruthenium (II). Organometallics 1998, 17, 1741-1749.

(34) Govindaswamy, P.; Linder, D.; Lacour, J.; Süss-Fink, G.; Therrien, B. Chiral or Not Chiral? A Case Study of the Hexanuclear Metalloprisms $[\mathrm{Cp}(6) \mathrm{M}(6)($ micro(3)-Tpt-kappaN)(2)(micro-C2O4kappaO $)(3)] 6+(\mathrm{M}=\mathrm{Rh}, \mathrm{Ir}, \mathrm{Tpt}=2,4,6-$ Tri $($ pyridin-4-Yl $)-1,3,5-$ Triazine. Dalton Trans. 2007, 6, 4457-4463.

(35) Dapprich, S.; Frenking, G. Investigation of Donor-Acceptor Interactions: A Charge Decomposition Analysis Using Fragment Molecular Orbitals. I. Phys. Chem. 1995, 99, 9352-9362.

(36) Nogueira, G.; Dömötör, O.; Pilon, A.; Robalo, M. P.; Avecilla, F.; Garcia, M. H.; Enyedy, É. A.; Valente, A. $\eta 6-(2-P h e n o x y e t h a n o l)$ ruthenium(II)-Complexes of 2,2'-Bipyridine and Its Derivatives: Solution Speciation and Kinetic Behaviour. I. Organomet. Chem. 2016, 820, 20-29.

(37) Gottesman, M. M.; Fojo, T.; Bates, S. E. Multidrug Resistance in Cancer: Role of Atp-Dependent Transporters. Nat. Rev. Cancer 2002, $2,48-58$.

(38) Aird, R. E.; Cummings, J.; Ritchie, a a; Muir, M.; Morris, R. E.; Chen, H.; Sadler, P. J.; Jodrell, D. I. In Vitro and in Vivo Activity and Cross Resistance Profiles of Novel ruthenium(II) Organometallic Arene Complexes in Human Ovarian Cancer. Br. I. Cancer 2002, 86, $1652-1657$.

(39) Guerriero, A.; Oberhauser, W.; Riedel, T.; Peruzzini, M.; Dyson, P. J.; Gonsalvi, L. New Class of Half-Sandwich Ruthenium(II) Arene Complexes Bearing the Water-Soluble CAP Ligand as an in Vitro Anticancer Agent. Inorg. Chem. 2017, 56, 5514-5518.

(40) Renfrew, A. K.; Phillips, A. D.; Tapavicza, E.; Scopelliti, R.; Rothlisberger, U.; Dyson, P. J. Tuning the Efficacy of ruthenium(II)Arene (RAPTA) Antitumor Compounds with Fluorinated Arene Ligands. Organometallics 2009, 28, 5061-5071.

(41) Wilfred, L. E A.; Christina, Li Lin Chai. Purification of Laboratory Chemicals, 5th ed.; Elsevier Science: 2003.

(42) Sheldrick, G. M. SADABS, version 2.10; University of Göttingen: Germany, 2004.

(43) Sheldrick, G. M. Crystal Structure Refinement with SHELXL. Acta Crystallogr., Sect. C: Struct. Chem. 2015, 71, 3-8.

(44) Zhao, Y.; Truhlar, D. G. The M06 Suite of Density Functionals for Main Group Thermochemistry, Thermochemical Kinetics, Noncovalent Interactions, Excited States, and Transition Elements: Two New Functionals and Systematic Testing of Four M06-Class
Functionals and 12 Other Function. Theor. Chem. Acc. 2008, 120, 215-241.

(45) Zhao, Y.; Truhlar, D. G. A New Local Density Functional for Main-Group Thermochemistry, Transition Metal Bonding, Thermochemical Kinetics, and Noncovalent Interactions. I. Chem. Phvs. 2006, 125, 194101.

(46) Frisch, M. J.; Trucks, G. W.; Schlegel, H. B.; Scuseria, G. E.; Robb, M. A.; Cheeseman, J. R.; Scalmani, G.; Barone, V.; Petersson, G. A.; Nakatsuji, H.; Li, X.; Caricato, M.; Marenich, A.; Bloino, J.; Janesko, B. G.; Gomperts, R.; Mennucci, B.; Hratchian, H. P.; Ortiz, J. V.; Fox, D. J. Gaussian 09, revision C.01; Gaussian, Inc.: Wallingford, CT, 2016.

(47) Hay, P. J.; Wadt, W. R. Ab Initio Effective Core Potentials for Molecular Calculations. Potentials for $\mathrm{K}$ to $\mathrm{Au}$ Including the Outermost Core Orbitals. I. Chem. Phys. 1985, 82, 299-310.

(48) Hay, P. J.; Wadt, W. R. Ab Initio Effective Core Potentials for Molecular Calculations. Potentials for the Transition Metal Atoms Sc to Hg. I. Chem. Phvs. 1985, 82, 270-283.

(49) Tenderholt, A. L. QMForge: A Program to Analyze Quantum Chemistry Calculations.

(50) Marenich, A. V.; Cramer, C. J.; Truhlar, D. G. Unviersal Solvation Modle Based on Solute Electron Density and a Contiuum Model of the Solvent Defind by the Bulk Dielectric Constant and Atomic Surface Tensions. I. Phys. Chem. B 2009, 113, 6378-6396.

(51) Truhlar, D. G. Valence Bond Theory for Chemical Dynamics. I. Comput. Chem. 2007, 28, 73-86.

(52) Arnaud, O.; Koubeissi, A.; Ettouati, L.; Terreux, R.; Alamé, G.; Grenot, C.; Dumontet, C.; Di Pietro, A.; Paris, J.; Falson, P. Potent and Fully Noncompetitive Peptidomimetic Inhibitor of Multidrug Resistance P-Glycoprotein. I. Med. Chem. 2010, 53, 6720-6729.

(53) Gilson, P.; Josa-Prado, F.; Beauvineau, C.; Naud-Martin, D.; Vanwonterghem, L.; Mahuteau-Betzer, F.; Moreno, A.; Falson, P.; Lafanechère, L.; Frachet, V.; Coll, J. L.; Fernando Díaz, J.; Hurbin, A.; Busser, B. Identification of Pyrrolopyrimidine Derivative PP-13 as a Novel Microtubule-Destabilizing Agent with Promising Anticancer Properties. Sci. Rep. 2017, 7, 10209.

(54) Baiceanu, E.; Nguyen, K. A.; Gonzalez-Lobato, L.; Nasr, R.; Baubichon-Cortay, H.; Loghin, F.; Le Borgne, M.; Chow, L.; Boumendjel, A.; Peuchmaur, M.; Falson, P. 2-Indolylmethylenebenzofuranones as First Effective Inhibitors of ABCC2. Eur. I. Med. Chem. 2016, 122, 408-418. 